University of Louisville

ThinkIR: The University of Louisville's Institutional Repository

Electronic Theses and Dissertations

$12-1946$

\title{
Ethylcellulose lacquer coatings for polystyrene plastics.
}

Stuart V. Heil

University of Louisville

Follow this and additional works at: https://ir.library.louisville.edu/etd

Part of the Chemical Engineering Commons

\section{Recommended Citation}

Heil, Stuart V., "Ethylcellulose lacquer coatings for polystyrene plastics." (1946). Electronic Theses and Dissertations. Paper 1974.

https://doi.org/10.18297/etd/1974

This Master's Thesis is brought to you for free and open access by ThinkIR: The University of Louisville's Institutional Repository. It has been accepted for inclusion in Electronic Theses and Dissertations by an authorized administrator of ThinkIR: The University of Louisville's Institutional Repository. This title appears here courtesy of the author, who has retained all other copyrights. For more information, please contact thinkir@louisville.edu. 
UNIVERSITY OF LOUISVILEE

ETHYLCELLULOSE LACQUER COATINGS FOR POLYSTYRUNE PLASTICS

\author{
A Thesis \\ Submitted to the Faculty \\ of the Graduate School \\ of the University of Louisville \\ in Partial Fulfillment \\ of the Requirements \\ for the Degree of \\ MASTER OF CHHAICAL ENGINLERING
}

Department of Chemical Engineering

Stuart V. ${ }_{\prime \prime \prime}$ eil

December, 1946 


\section{UNIVERSITY}

LIBRARIES

This PDF document is a scanned copy of a paper manuscript housed in the University of Louisville (UofL) Libraries. The quality of this reproduction is greatly dependent upon the condition of the original paper copy. Indistinct print and poor quality illustrations are a direct reflection of the quality of materials that are available for scanning. The UofL Libraries greatly appreciates any better copies that can be made available for replacement scans. 
ETHYTCFILULOSF: LACQUER COATINGS FOR FOLYSTYRMNE ILASTICS

Stuart V. Heil

Approved by the Examining Committee.

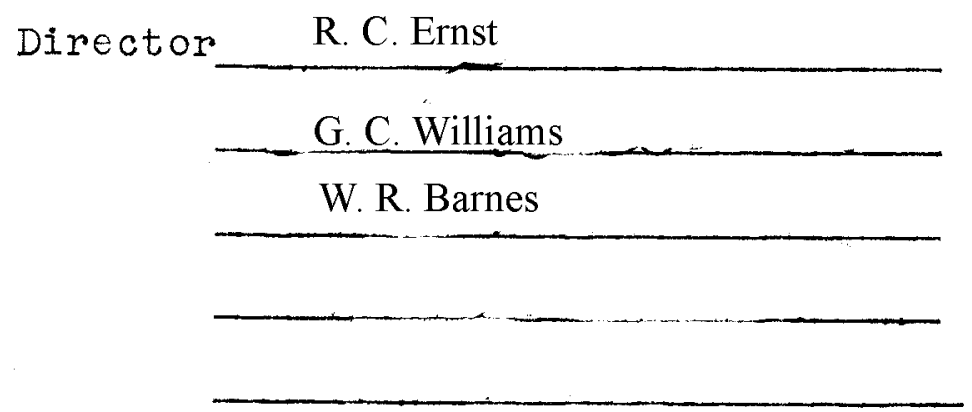

December, 1546 
CONTENTS

Page

List of Tables. . . . . . . . . . . . . . . iv List of Figures . . . . . . . . . . . . . . iv Acknowledgment. . . . . . . . . . . . . . v Abstract. . . . . . . . . . . . . . . . vi Introduction. . . . . . . . . . . . . . 1 Historical. . . . . . . . . . . . . . 3 Theoretical . . . . . . . . . . . . . 8 Experimental. . . . . . . . . . . . . 23 Discussion. . . . . . . . . . . . . 67 Summary and Conclusions . . . . . . . . . 70 Literature Cited. . . . . . . . . . . . 72 Acknowledgment. . . . . . . . . . . . . 74 vita. . . . . . . . . . . . . . . . 75 


\section{LIST OF TABLES}

Page

I Formulations of Preliminary Solvent

Mixtures .................. 27

II Results of Resin Evaluation by Means of

Trial Lacquers . . . . . . . . . . 30

II Evaluation of Resins by Means of Modified

Lacquers . . . . . . . . . . . . 32

IV Hardness and Adhesion Tests on Films of Pure Resin . . . . . . . . . . . 33

$V \quad$ Experimental Solids Compositions used in

Plotting the Trilinear Diagram . . . . . 35

VI Relative Evaporation Rates of Solvent Mixtures... . . . . . . . . 40

VII Results on Lacquers Formulated by Neans of

Relative Evaporation Rates . . . . . . 41

VIII Effect of Additions of n-Butanol to

Formulation A-38 . . . . . . . . . 43

IX Effect of Solvent Mixtures on Folystyrene..46

X Results of Plasticizer Spot Tests. . . . 50

XI Formulations of Experimental Lacquers. . . 51

XII Formulation of Thinners for Experimental

Lacquers . . . . . . . . . . . 56

LIST OF FIGURES

I Trilinear Diagram Showing Effect of Change in Composition on the Physical Properties of Lacquer. . . . . . . . 37 
Acknowledgement

The author wishes to acknowledge the kind assistance and helpful guidance of Dr. R.C. Ernst who directed this research. 


\section{ABSTRACT}

An ethylcellulose lacquer system for both decorative and protective purposes was developed for use on polystyrene plastics. It was found that a one-coat lacquer containing only alcohol solvents produced the most satisfactory finish.

Formulations were based on experimental work, conducted to determine the effect of the various lacquer components on the plastic. The results of a study of formulations on a two-coat system are presented. 
INTRODUCTION 
INTRODUCTION

During World War II volume production of styrene was begun because of its use in the manufacture of synthetic tires. Now that this outlet has been somewhat curtailed, other uses of styrene are desired. Styrene in polymerized form ras been used for some time in the plastics field. Folystyrene combines a number of attractive properties, the most important being transparency, resistance to chemicals, excellent electrical properties, and high strength at low temperatures. It is available in a wide range of colors from crystal clear through all transparent shades to translucent and opaque.

It has been felt that the value of the plastic could be increased by the application of decorative coatings to the end products. This coating would not only increase the attractiveness of the products, but would also cover any slight molding imperfection which might be present.

The most desirable coating is one which may be applied by spraying, and which dries very rapidly. Therefore, it was thought that a lacquer would be most suitable. It is known that polystyrene is soluble in almost all the organic solvents, with the exception of alcohols and petroleum derivatives. The active solvents are absorbed by the plastic in an unknown manner and result in a crazing effect which extends deeply into the material. The problem 
of the solvents to be employed, therefore, is one of the more important ones. Because of the wide range of solubility of polystyrene, etrylceliulose was chosen as the cellulosic derivative. Thus, solvents with less rigorous action could be used. The regular requirements of a lacquer gloss, hardness, and durability must also be fulfilied.

The purpose of this investigation was to formulate a lacquer which met these specifications. The major portion of the work was of an experimental nature, and was divided into two parts: first, the formulation of a lacquer containing only alcohols as solvent and deriving the necessary - adhesion from the resin; second, formulation of a lacquer which contained hydrocarbons and in which adhesion was obtained from solvent action or solvent bite. These two systems were explored, and the work was concluded when lacquers having hardness, adresion, and gloss were obtained. Future work may reveal other systems which are equally satisfactory. 
HISTORICAL 


\section{HISRORICAL}

Ethylcellulose

Although cellulose has been known to exist for centuries, and the first practical uses of nitrocellulose were made in 1848 by haynard (20) and Bigelow (4), ethylcellulose is a relatively recent discovery in the cellulosic derivatives. Suida (28) found that cotton fibre could be dyed more easily after a treatment of caustic and ethyl sulphate. This was the first idea of etherfication of cellulose, and took place in 1905. Following.this, patents were obtained by Leuchs (14), Lilienfeld (15), Dreyfus (8), and a number of others. Of these, Lilienfeld's contribution is the most noteworthy. In 1912 he presented detailed studies of ethylcellulose and its properties and recognized its potential use in coatings, plastics, and rayon. Denham et al (6) showed that the ethers could be produced by the substitution of alkyl or aryl radicals in place of a hydroxyl hydrogen atom in the cellulose molecule. At this time, the preparation of the ether was definitely known, but the high cost of manufacture prevented the wide use which was indicated. During the next 25 years, were done large amounts of development work which is described only in the patent literature (2S). During this period ethylcellulose was produced on a small scale in Germany. It was imported to this country for use in a few specialties where cost of raw mate- 
rials was unimportant.

The industrial growth of ethylcellulose began in 1835, when American production methods and lower costs of raw materials combined to make it available in a price range at which its use was greatly stimulated. New uses developed rapidiy, as domestic producers passed on the benefits of process improvements and increased volume production in the form of price reductions. Fthylcellulose is now a standard article of commerce whose range of utility is widening as formulators appreciate that its properties and versatility adapt it to the solution of a wide variety of protective coatings problems (18). The two main American producers of ethylceliulose are the Dow Chemical Company, Midland, Michigan, (7), and Hercules Powder Company, Wilmington, Delaware (11).

\section{Polystyrene}

Historically, polystyrene is not new. The styrene monomer was first isolated by the distiliation of purified form of balsam known as storax, in 1831. In 1839, Simon (26), noted the thermo-polymerization of styrene in the presence of sunlight. Thirty years elapsed, during which many investigators made public their findings (G) in various journals. Then Berthelot (3), the French chemist, discovered the synthesis of styrene from ethylene and benzene by pyrolysis in a red-hot tube. Work of a theoretical nature continued until the first recorded patents disclosing the possible uses 
of styrene were granted to F. E. Matthews (16, 17) of London in 1911. Dr. Matthews observed the excelient insulating properties of polymerized styrene and felt that it would be an improvement over the then known materials for electrial application (21).

Since then, 1911, the popularity of polystyrene for molding material has been increasing in Europe. Not until 1933 was American interest garnered, when domestic industry began a thorough investigation of the material (21). Only after several years of intensive work did it become possible, in 1927, for American companies to produce a material of high quality in commercial quantities at a price comparing favorably with that of other plastic materials. Today, polystyrene is produced in the United States by Catalin Corporation, New York, N.Y.; the Dow Chemical Company, Midiand, Michigan; Bakelite Corporation, New York, N.Y.; and Monsanto Chamical Company, Springfield, Mass.

\section{Lacquers}

Attempts to prepare protective coatings are as old as man himself. The record of the oldest coating is found in the Book of Genesis. Archeological findings have shown that improvements in the art have followed very closely to the rise of the various civilized cultures. The first lacquer type of coating which appeared in China and Japan in the 13th Century B.C., consisted of tree saps and natural resins dissolved in simple solvents. This form was essentially unchanged, 
until 1848 when Maynard (20)and Blgelow (4) used a solution of cellulose nitrate to form a coating. The term lacquer tocay denotes a coating which drys by evaporation rather than oxidation and further implies a coating which utilizes cellulosic derivatives for the film forming ingredient (19).

The greatest of the pioneers, Alexander Parkes (22), realized the advantages of nitrocellulose as a film forming material, but the available solvents proved to be a handicap to him. The evaporation rates of the known solvents were too great, and the films deposited were white, opaque, and of low tensile strength. Undaunted, Parkes continued his work, and in 1864 discovered the advantages offered by plasticization of the films. Nitrocellulose lacquers may be said to have originated in 1882 when stevens (27) patented the use of amyl acetate as a solvent for nitrocellulose. This solvent, for the first time, permitted the deposition of a hard, lustrous, transparent film or cellulose with good durability. The high viscosity of the cellulose solution made it suitable only for specialities such as brass and silver lacquering and in the production of leather. The rise of this new industry created a vast demand for solvents with the result that new and vastly improved methods of fermenting grain were developed for their production. The developements proved it possible to produce enough amyl and butyl alcohol to staisfy the needs of the industry until the advent of synthesized butanol. The next advancement of significance 
was the patenting of a process for reducing the viscosity of the nitrocellulose so that a practical amount of solids could be sprayed.

Varnishes were first replaced by lacquer in the automotive industry, when automobile finishers realized the advantages of cellulose coatings. Use of the lacquers enabled production schedules to be speeded up from two weeks for the old slow drying varnish to a few days. The lacquer finishes also had the added advantages of greater durability, ease of application, and resistance to gasoline and acids. Lacquers have contained this replacement of other types of finishes in many industries requiring protective coatings. The use of cellulosic derivatives has been further developed by the discovery of many new plasticizers and synthetic resins, until it has become one of our major industries. It has established a permanent place for itself in the finishing industries.

Although, primarily, nitrocellulose has been used, new cellulose derivatives are being developed and are replacing this early derivative in various fields because of their more desirable properties. The most notable of these in the coatings work is ethylcellulose. Use and application is still in the experimental stage. The little information which is available may be found in the literature (1, 2), literature of the companies producing it $(7,11,25,5)$ and in experimental work published at various colleges (10, 12, $13,23,24,30)$. 
THHORETICAI 
THEORETICAL

\section{Ethylcellulose}

Chemically, ethylcellulose is an ether of cellulose and ethyl alcohol. It is manufactured from alpha cellulose, caustic soda, and ethyl chloride. Purified cellulose, whether from cotton linters or from wood pulp, is converted to alkali cellulose by treating it with concentrated caustic soda. The uniformity of treatment and the ratio of caustic soda and of water to cellulose are very closely controlled. Since these factors very largely determine the degree of ethylation and the uniformity of behavior of ethylcellulose in solvents. The alkali cellulose is reacted with ethyl chloride in autoclaves until the desired ethoxy content and solubility are obtained. The reaction mass is treated to recover unreacted ethyl chloride and solvent by-products. The ethylcellulose is precipitated with hot water as fine porous granules which are then washed free of salt and aried. The reaction in the autoclave may be expressed by the type reaction

\section{$\mathrm{RONA}+\mathrm{C}_{2} \mathrm{H}_{6} \mathrm{Cl} \longrightarrow \mathrm{ROC}_{2} \mathrm{H}_{5}+\mathrm{NaCl}$}

in which the cellulose radical is represented by $R$ ( 11 ). There is some doubt about the exact structure of the cellulose molecule. The most widely accepted theory of structure for the cellulose molecule is a chain of cellobiose units, each composed of two glucose residues, bound together 
by oxygen linkages.

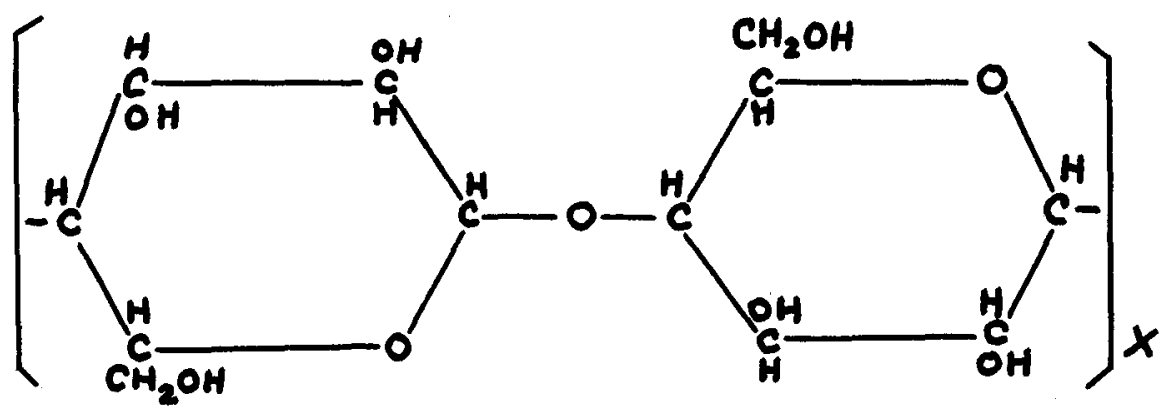

These long chains of oxygen linked cellobiose units have great strength which is passed on to its derivatives, such as ethylcellulose, nitrocellulose and cellulose acetate. The desirable properties of flexibility and toughness in these materials are directly attributable to this long chain structure.

From the formula given previously, it is seen that each glucose residue has three hydroxyl groups which are available, in toto or in part, or the reaction noted above. The triethyl compound possessing a substitution value of 3 or $54.88 \%$ ethoxyl content may be obtained from the complete substitution of all three replaceable hydroxyl groups. Diagrammatically this molecule may be given by

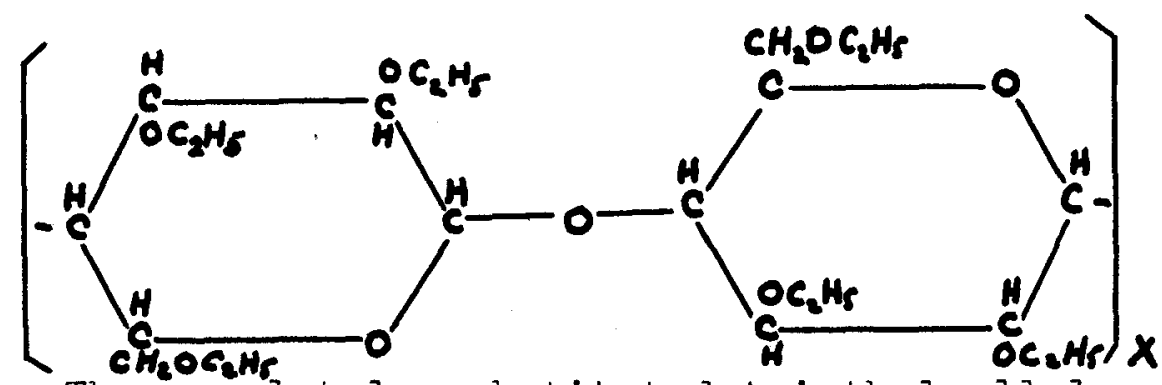

The completely substituted triethylcellulose has no commercial significance, however, because it lacks strength 
and flexibility, is not thermoplastic, and shows extremely limited compatibility and solubility. The commercial product which exhibits the remarkable combination of useful properties, has a substitution value between 2.15 and 2.58 ethoxy groups per glucose unit, or $43.5 \%$ to $49.5 \%$ ethoxyl content.

The versatility of ethylcellulose in coatings, films, and plastics is increased because certain of its physical properties vary considerably with its ethoxy content. Ethylcelluloses having an ethoxy content of 47.5 to $50.0 \%$ are the ones principally used for general-purpose coating compositions because they have the greatest solubility in solvents and the widest compatibility with plasticizers, resins, waxes, and varnish oils.

Although ethylcellulose, as received from the manufacturer, appears as a white granular solid, the film of ethylcellulose deposited from a lacquer is practically colorless; therefore it is not affected by sunlight or ultraviolet light. Accurate color control can be obtained through the use of dyes and pigments.

Ethylcellulose has compatibility properties which compare very facorably with nitrocellulose. Ethylcellulose yields clear films with a wider variety of plasticizers and resins than other cellulose derivatives, including waxes and oils. This excellent compatibility of ethylcellulose is one of the prime factors in its suitability for use in lacquers. The low density of ethylcellulose is important; con- 
sequently ethylcellulose yields a greater volume of film forming solids per unit weight than any other commercial cellulose derivative. The coverage per unit weight amounts to $20 \%$ more area than cellulose acetate and about $45 \%$ more area than nitrocellulose, in coatings.

The ether does not discolor on exposure to strong sunlight nor does it promote the discoloration of resins or plasticizers. This characteristic makes it possible to prepare permanently white lacquers and plactic.

Ethylcellulose dissolves in a wider variety of solvents than any other cellulosic derivative. It is soluble in such low cost solvents as coal tar hydrocarbons, high aromatic content petroleum naptha, and alcohols. Even the ourely aliphatic napthas are latentsolvents, for higher ethoxy-content ethylcellulose, since it will dissolve in mixtures of these napthas with relatively small proportions of alcohol.

The films prepared from ethylcellulose are highly flexible and retain their flexibility at temperatures well below freezing. Wthylcellulose imparts flexibility, toughness, and cold-check resistance to lacquer and vamish films. It is useful flexibilizing agent for nitrocellulose lacquers. Ethylcellulose will melt when exposed to an open flame and when once ignited will support combustion. Because of its low flammability, ethylcellulose of ers no greater fire hazard on storage or handing than does paper or cellulose 
in the same physical form. The material may be rendered noninflammable in coatings and plastics by the use of suitable plasticizers. It may be hot colloided and worked in a plastic condition without fear of spontaneous ignition or decomposition.

Other important physical properties of ethylcellulose are light stability; chemical resistance, which is superior to other cellulosic materials; water resistance; thermal stability; and toughness. All these properties combine to make ethylcellulose a raw material suitable for lacquer formulation.

\section{Polystyrene}

Chemically, styrene is prepared by the removal of hydrogen from ethyl benzene. The ethyl benzene is obtained, to some extent, from natural sources or from direct syntheses. A familiar process involves the use of ethyl chloride and benzene to form ethylbenzene, which is cracked to form styrene, as shown in the following reaction:

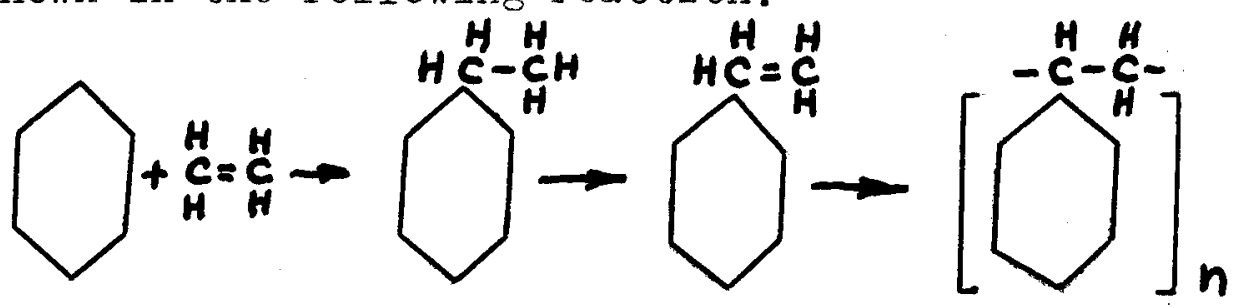

Styrene can then be polymerized through the action of heat, light or catalyst, or combinations of them. In general, the more rapid the rate of polymerization through trie effect of heat or catalyst, the lower the molecular weignt and viscosity of the resulting polymer. While all 
investigators do not agree, it is felt that tre polymerization of styrene is a chain reaction. There appears to be a small amount of cross linkage between chains, attributable to impurities. This is affected to some degree by the rate of polymerization. The rate of polymerization also affects the molecular distribution or the range of molecular weights within a given polymer. In general it has been found that moleuclar weights from 40,000 to 140,000 are more advantageous for injection molding while the lower molecular weights, that is, down to 35,000 , appear more suitable for resin modifying and coating apslications.

$$
\text { Polystyrene is then, a long methylene chain sub- }
$$

stituted alternately by phenyl groups. This conception of the molecular structure is confirmed by meansurements of light absorption and Ramn spectra of solutions which indicate an alkylbenzene structure for the polymer. The end valences may be satisfied by (1) migration of an H-atom from one end of the chain to the other, or from one chain to another:

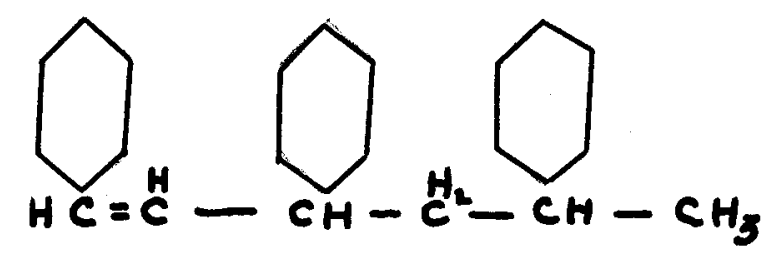

(2) Combination with a catalyst $\mathrm{A}-\mathrm{B}$, or solvent molecules and impurities present:

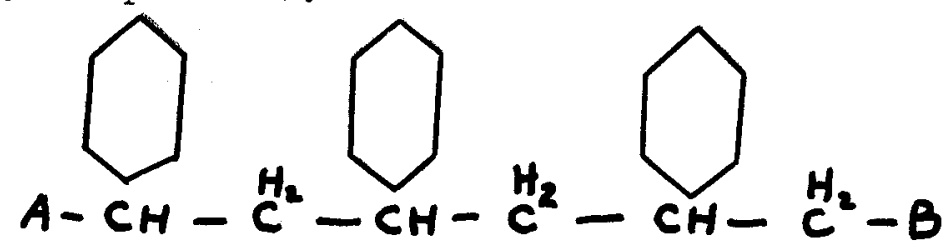


or (3) cyclization, ring formation by the union of the two ends of the chain. The structure would then become a flattened ring or double chain:

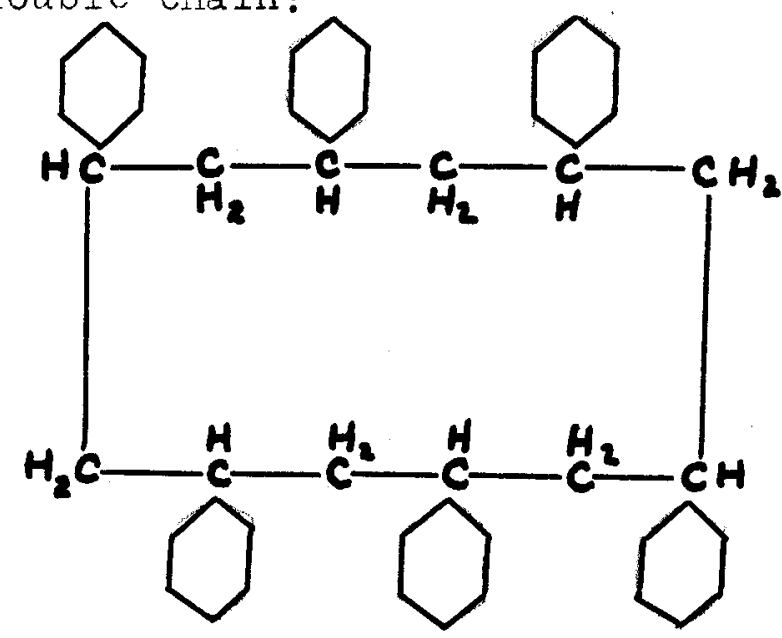

The question of the nature of the end groups of the polystyrene chain is still undecided.

While polystyrene will accept plasticizers, there appears to be little gained through the use of these added agents at room temperature. Polystyrene can, however, be supplied in several ranges of flow. The various glow grades are not accomplished through plasticization but rather through a control of molecular weight and molecular distribution. These molecular weights can be controlled through polymerization as mentioned above and through controlled milling. The use of srall amounts of lubricants to improve flow and to aid in ejecting molded pieces has been found advantageous for some complicated molding problems. Since polystyrene contains no plasticizer, there is no material to be removed on exposure; consequently the product exhibits dimensional stability. 
Since polystyrene is a thermoplastic material, it is most conveniently and economically handled by the injection process. The maximum number of pieces from each pound of material may be obtained because polystyrene has the lowest specific gravity ( 1.07 ) of any of the commercial injection materials.

Polystyrene is a clear, crystal line thermoplastic with no odor or taste. Available colors range from crystal clear through all transparent shades to translucent and opaque.

The resistance of this material to water is phenomenal, the water absorption being so low as to be measurable only on the most sensitive equipment. Consequently, it is not affected by humid conditions or actual contact with water from the standpoint of moldability, color bleaching, or dimensional stability.

Polystyrene has a comparatively high modulus of elasticity and makes excellent rigid moldings. It has a high heat distortion point and exhibits practically no cold flow at room temperature, even under high loads. Electrically, polystyrene has the lowest power loss of any plastic material, in most forms being equivalent to fused quartz.

Chemically, polystyrene is generally unaffected by any inorganic solutions, such as salts, acids, or bases. It is insoluble in petroleum hydrocarbons, low aliphatic alcohols, glycol ethers, and some organic acid esters. It is sufficient- 
Iy soluble in coal tar hydrocarbons, chlorinated hydrocarbons, and the acetic esters of the lower aliphatic alcohols to make it of interest as a lacquer and coating modifying agent. Some materials, whether active solvents or not, have a tendency to penetrate the plastic and cause crazing. This crazing, if deep enough, may cause the destruction of a molaed piece.

Because of its attractive properties, polystyrene is used in radio insulators, electrical products, medicinal equipment, and novelties of many kinds.

\section{Lacquers}

Many types of coatings have appeared under the title of "Lacquer" (19), but the word today denotes a protective coating which contains a cellulosic derivative as the major film forming constituent. The other materials which are combined to make the finished lacquer are resin, pigment, plast1cizer, solvent, and diluent. The first three of these, together with the cellulose, constitute the non-volatile portion of the lacquer. The solvent and diluent are known as the volatile ingredients. These components will be discussed in detail later. Lacquers are distinguished from oleoresinous finishes because they harden and form films primarily by the evacoration of the solvent present, rather than by polymerization and oxidation of the constituents. Lacquers present numerous advantages over the oleoresinous coatings for the following reasons: they dry by evaporation, a fast 
process compared with the relatively slow process of oxidation which causes the air drying of oleoresinous finishes; more uniform products are obtained becalise of close chemical control; the manufacture and control are more of a chemical technical problem than the making of varnishes and paints; they have remarkable durability, water resistance, mar and abrasion resistance, hardness, color retention, chemical resistance, flexibility, and toughness. All these characteristics have combined to give lacquers the popularity they enjoy today.

$$
\text { of the permanent, film-forming materials in the }
$$

lacquer, the cellulose derivative actually gives the resultant film the properties most truly characteristic of a lacquer finish. By the addition of cellulosic materials the film is greatly improved with respect to rapid setting, resistance to heat, water, and chemical attack. Ethylcellulose will provide all these advantages, especially in regard to toughness and chemical resistance, as well as heat stability, flexibility, light stability and low flammability.

Resins are added to cellulose derivatives in an attempt to introduce some of the desirable properties of a varnish. They perform various functions, some of which are to increase adhesion, body, depth, gloss, luster, brilliance, durability, water resistance, and to increase the solids content of the lacquer without raising the cost or viscosity of the lacquer. The most suitable resins are those which are 
soluble in the lacquer solvent mixtures and give a clear, transparent film, with a good, permanent gloss. Naturally, the resin must also be compatible with the cellulosic material. The resins are of three types; natural, semi-synthetic, and synthetic. The natural gums previously found the widest use because of their low cost. Typical of this class are damar and shellac. Of the semi-synthetic type, estergum, a glycerol ester of rosin acids, is probably the most widely used. The synthetic resins are the recently developed materials capable of producing lacquers that are far superior to those made from the natural gums. These new resins are chemical combinations of such compounds as glycerol, phthalic anhydride, and fatty acids; phenol and formaldehyde; urea and formaldehyde; and various other polymers.

Plasticizers serve to improve the lacquer film in numerous ways. Their main purpose is to improve the flexibility of the film thus increasing its durability under adverse conditions. The cellulose film without plasticizer has a decided tendency to shrink and pull away from the surface to which it is aplied. A properly plasticized film will resist the severe variations of temperature when exposed to the elements, and will retain its elasticity indefinitely. To obtain certain desired results, however, it is necessary to gage properly the amount of plasticizer to be used when formulating a product since it is often advisable to limit the degree of elasticity. An increase in plasti- 
cizer may cause a decrease in lacquer hardness and may even make the lacquer permanently tacky. Plasticizer may also be classified into three types: o11s, true cellulose solvents - (chemical plasticizers), and resins of liquid consistency. Castor oil is representative of the first class and, because of its nonoxidizing properties and low cost, is by far the most widely used. As the oils are generally considered to be dispersed throughout the film in minute globules, they are not so efficient in plasticizing effect as the chemical plasticizers. The second class consists of such compounds as di-butyl phthalate, tricresyl phosphate, and tri-phenyl phosphate. The chemical plasticizers have less tendency to sweat or spew out of the film under heat, have less odor, greater stability, and though usually more expensive than the oils, they are used in considerable volume. The third class has been developed recently and includes such compounds as methyl, ethyl, and benzyl abietate, some of the chiorinated diphenyls, toluol-sulphonamide-aldehyde resins, and many of the softer varieties of alkyd resins. Besides being practically non-volatile, plasticizers should be water-white in color, non-tuxic, and free from residual odors. At the same time they should possess high solvent strength, low flammability, and chemical and light stability. Pigments, or dyes, are incorporated in lacquers to give the desired color. Here is noticed a marked difference in the pigmentation of oleoresinous paints and enamels, and 
lacquers. Whereas an average paint might contain six or eight pounds of pigments to a gallon, an attempt to use an equal amount in a lacquer formula would give a product of poor durability and no adhesion. The high volatile content of lacquers as compared with oleoresinous materials shows that there is less binder to hold the pigment particles together. Thus the pigments used in lacquers are somewhat different from those used in other types of finishing materials. In general, the pigments of greatest strength and hiding capacity and low oil absorption give the best results. Besides imparting color to lacquer pigments also serve to protect it for exterior use by preventing penetration of the actinic rays of sunlight, which cause rapid decomposition and disintegration of a clear film. Pigments of high opacity enable the production of automotive and other exterior lacquer enamels which surpass in durability the best exterior oleoresinous and synthetic paints and enamels.

Although none of the volatile portion of lacquer appears in the final film, it serves a very important function. The solvent-diluent portion of the lacquer puts the constituents in a workable liquid form so that it may be applied. The formulation of the solvent mixture is one of the most important parts of lacquer technology.

The true solvent portion of the volatile constituents must be divided into two parts: First, the cellulose solvent, and second, the resin solvent. In this work, only solvents 
for ethylcellulose need be considered when dealing with the cellulose solvents. Because of its wide solubility, esters, ketones, ethers, aromatics and alcohols may be employed as ethylcellulose solvents. The best resin solvents and also those that can be used for practically any resin are the aromatics, namely benzol, xylol, and toluol. Most resins are rather widely soluble materials. The last portion of the volatile components are the diluents. In the main these materials are composed of petroleum napthas, either in their natural state or after they have been hydrogenated. These diluents are added for economic reasons because of the high cost of the true solvents. The extent to which they can be used depends upon the tolerance of the cellulose derivative and resin solvents as well as the cellulose derivative and resin itself.

In general no one solvent possesses all the requirements necessary to make a satisfactory lacquer; a blend of several solvents is necessary. The ideal solvent should be a good solvent for both the cellulose and the resin in the lacquer. To secure a perfectly clear, homogeneous film and to minimize the tendency towards blushing, particularly in the faster-drying lacquer, the solvent sho Id be preferably non-hygroscopic, and not miscible with water. The presence of higher boiling solvents, which evaporate more slowly from the film, will counteract the effect of such fast evaporating solvents which may of necessity be present in the formulation. 
The odor of solvents or diluents is of importance because most lacquers are applied indoors, where the usual method of spray application may throw a large amount of vapor into the atmosphere in a short time. Solvents and diluents should be pale or water-white, particularly when used in clear lacquers, white, and delicate tint lacquer enamels. This color requirement is important not only in the original liquid state but also during storage in drums and metal containers. Any solvent which has a tendency to darken through oxidation or resinification during storage is deleterious to best results. Toxicity of solvents is another important consideration, particularly when the lacquer user may be exposed to considerable volume of the vapors. 
EXPERIMENTAL 
EXPERINENT AL

Equipment

The equipment used throughout this work was of the type usually found in a paint laboratory. The units were all small. The major pieces used were the following:

1) Laboratory mixes - This piece consisted of three rollers mounted in a horizontal plane. The center roller was driven by a small electric motor, and the other rollers were driven by friction from the paint cans themselves. In use, a can of lacquer was placed on the equipment so that it was in contact with the center and one outside roller, imparting to the can a rotary motion which aided the solution of the lacquer components. By this means, the lacquers could be completely mixed in 10 hours.

2) Differential-speed Roller Mill - Here again three rolls were mounted in a horizontal plane. All three of the rolls were driven. The two outside rolls had an adjustment screw, by means of which the distance between these rolls and the center roll could be changed. Each roll was driven at a different speed, to increase the fluid shear between the rolls. The ratio of speeds was approximately $1: 2 \cdot 3: 3$. This device was used to incorporate pigment into the lacquer. The action of the mill was dispersive, and not one of size reduction. The use of this equipment made it possible to produce good gloss 
in the finished product.

3) Spraying Equipment - The spraying equipment was of an ordinary type, made by the Devilbiss Manufacturing Company . 


\section{PROCEDURE}

Throughout this work, the formulation will be divided in two parts, I) solids, constituents to be reported as percentage of total solids, and 2) solvents, constituents reported as percentage of total solvent. The amount of solvent mixture to be added to a given weight of solids will be reported. Thus, a typical formulation would appear as

$\begin{array}{ll}\text { Solids } & \text { Ethylcellulose } \\ & \text { Resin } \\ & \text { Plasticizer }\end{array}$

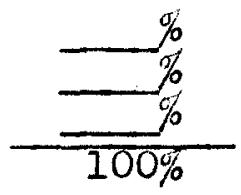

Dissolve and cut to spraying viscosity (17\% solids) with

$\begin{array}{ll}\text { Solvent } & \text { Solvent } 1 \\ & \text { Solvent } 2 \\ \text { Solvent } 3\end{array}$

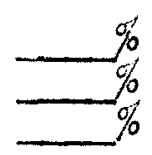

The percentages in all formulations indicate percent by weight.

Before being tested all panels were aged by being air dried for 24 hours and by being heated for one hour in a convection oven at $70^{\circ} \mathrm{C}$.

With the exception of several preliminary formulations, one solvent composition was used for both the lacquer and thinner. Two solvent formulations were used by previous lacquer investigators, one for lacquer makeup and one for spraying thinner. The use of two solvent mixtures leads to confusion as to the final solvent composition. When only one solvent formulation is used, the composition of the thinned lacquer is definitely known regardless of the dilution. Hence, the lacquer composition may be specified by giving the solids 
composition and the solvent composition together with thining instructions. Thining instructions are completed by speification of either the final solids composition or the final viscosity.

Preliminary work on the problem, including literature studies, showed that alcohols, pure or in mixtures of other alcohols, had absolutly no effect on the polystyrene plastic. Other types of solvent materials, whether they actually dissolve the plastic or not, showed some tendency to craze the plastic surface. For this reason, the work was divided into two parts. The first of these was the development of a lacquer containing only alcohols. This type of lacquer must, by necessity, derive its adhesion from the adhesion of the resin present. The second part of the work was the formulation of a lacquer which contained any type of solvent. Here, the adhesion is obtained by solvent bite.

\section{Part I: Alcohol Solvents}

A solvent mixture was designed containing only alcohols. The materials for use in this formulation were those which gave low, medium, and high boiling components in the final mixture. As a result, ethyl alcohol, butyl alcohol, isopropyl alcohol, and Cellosolve were chosen to give the required boiling point range. In order to determine the best combination of these solvents, the proportion of the various components were varied and made into lacquers. The solids content of these lacquers was the same in all formulations 
and was

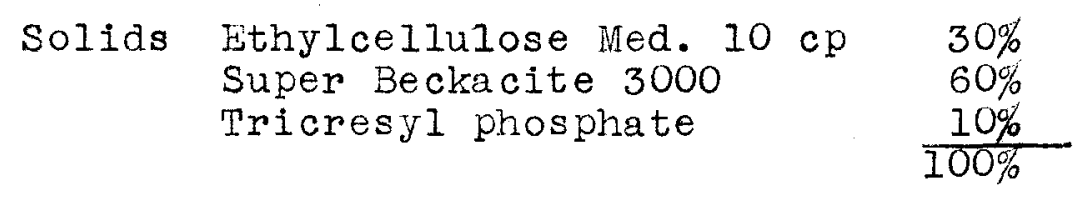

This formulation was chosen on the basis of previous experience. Super Beckacite 3000 and Tricresyl phosphate were used because of their availability, and medium-ethoxy Ethylcellulose was used on the recommendation of the manufacturer. These solvent formulations appear in Table $I$.

\section{Table I}

Formulations of Preliminary

Solvent Mixtures

Number

Cellosolve

$\left(\mathrm{C}_{2} \mathrm{H}_{5} \mathrm{OC}_{2} \mathrm{H}_{4} \mathrm{OH}\right)$

Isopropyl Alcohol 15

Ethyl Alcohol

Butyl Alcohol

$$
A-1
$$

30

50

5

$$
A-2
$$

50

10

30

10
$A-3$

40

12

40

8
A $-4 \quad A-5$

$20 \quad 25$

$20 \quad 10$

$60 \quad 55$

The resultant lacquers were examined for spraying and drying characteristics. Of the five, mixture A-4 gave the best results from both spraying and drying viewpoints. This mixture was then used in the following work.

The next phase of the work was the evaluation of different types of resins. It was desired to determine the hardness, adhesion, and gloss of the resins on a relative basis. For this work, a formulation was designed which made it possible to put the resins in a form which would allow 
comparison. The formulation, as designed, was not intended to be final but merely to see the relative merits of the resins. The formulation was:

$\begin{array}{llr}\text { Solids } & \text { Med. } 10 \text { cp Ethylcellulose } & 26 \% \\ & \text { Resin } & 60 \% \\ & \text { Tricresyl phosphate } & \frac{14 \%}{100 \%}\end{array}$

made into lacquer of $20 \%$ solids with

\begin{tabular}{llr} 
Solvent & Ethyl Alcohol & $60 \%$ \\
& Cellosolve & $20 \%$ \\
& Isopropyl Alcohol & $20 \%$ \\
\hline
\end{tabular}

The composition used here was based upon general lacquer practice. Medium-ethoxy Ethylcellulose was used upon the recommendation of the manufacturer. The Tricresyl phosphate is widely used in the lacquer industry and was used here because of availability. The resins which were used for the trials were

Zein A - A corn protein product suggested as a substitute for shellac prepared by Corn Products Co., New York, New York

Pontianak - A manila type natural resin distributed by The American Gum Importers Inc.

Nevillac Soft - A condensation product of phenol and coumarone-indene type unsaturates. Notable for its solubility. Produced by the Neville Co., Pittsburg, Penna.

Nevillac Hard - A resin similar to Nevillac Soft, but slightly higher melting point. Also made by the Neville Co.

Nevillac RT - Similar to other Nevillac Resins, but has slight modification. Another Neville Co. product.

Nevillac RF - Another modification of the basic Nevillac soft resin. Nade by the Neville Co.

Estergum 241 - A glycerol ester of rosin acids. This type, 241 , is specifically soluble in alcohols. Froduced by the Paramet Chemical Corp., Long Island City, New York 
Super Beckacite 3000 - A hard, pure phenolic resin made by Reichhold Chemicals Inc., Detroit, Michigan

Durez 550 - A soft, pure phenolic resin. A product of Durez Plastics and Chemicals Inc., North Tonawanda, N.Y.

Shellac - A natural resin with very good solubility in alcohol

Staybellite 742 - Hydrogenated rosin, prepared by the Hercules Fowder Co., Wilmington, Delaware

Amberol 750 - Fortified Rosin

Amberol 226 - Modified phenolic. Both Amberols are made by Resinous Products and Chemical Co., New York, N.Y.

The lacquers made from these resins were sprayed on small pieces of plastic, and the film was examined for hardness and adhesion. The results appear in Table II. The results in Table II showed that two of the resins, zein $A$ and Shellac, were unusable because of lack of solubility in the solvent mixture. Several other resins, including Ponitianak, Nevillac RT, Nevillac RF, Super Beckacite 3000, and the Amberols, were shown to have very low adhesive properties. Estergum, Staybelite, and Nevillacs Hard and Soft displayed qualities which led to consideration of their use.

The adhesion of the lacquer was checked by the standard knife-blade test. In this test the lacquer film is cut, by means of a knife, in a criss-cross manner with the cuts being spaced about $1 \mathrm{~mm}$. apart. The ease of removal of the small cut squares gives an index of the adhesion. At the same time, any brittleness will be snown.

The film hardness was measured by the use of standard pencils. A set of regular drafting pencils with a hardness 
Table II

Results of Resin Evaluation by

Means of Trial Lacquers

\begin{tabular}{|c|c|c|}
\hline No. & Resin & Results \\
\hline$A-6$ & Zein A $(x y-19)$ & $\begin{array}{l}\text { Resin insoluble in solvent mixture } \\
\text { employed }\end{array}$ \\
\hline$A-7$ & Pontianak 1472 & $\begin{array}{l}\text { No adhesion, brittle, poor surface } \\
5 \text { Hardness }\end{array}$ \\
\hline$A-8$ & Nevillac Soft & $\begin{array}{l}\text { Adhesion satisfactory, poor surface } \\
5 \mathrm{H} \text { hardness }\end{array}$ \\
\hline$A-9$ & Nevillac Hard & $\begin{array}{l}\text { Adhesion excellent, poor surface } \\
7 \mathrm{H} \text { hardness }\end{array}$ \\
\hline$A-10$ & Nevillac RT & $\begin{array}{l}\text { Low adhesion, brittle, poor surface, } \\
4 \text { H hardness }\end{array}$ \\
\hline$A-11$ & $N \in v i l l a c R P$ & Yoor adhesion, poor surface, $4 \mathrm{H}$ hardness \\
\hline$A-12$ & Estergum \#241 & $\begin{array}{l}\text { Adhesion satisfactory, poor surface } \\
5 \mathrm{H} \text { hardness }\end{array}$ \\
\hline$A-13$ & $\begin{array}{l}\text { Super Beckacite } \\
3000\end{array}$ & $\begin{array}{l}\text { No adhesion, brittle, poor surface } \\
7 \mathrm{H} \text { hardness }\end{array}$ \\
\hline$A-14$ & Durez 550 & $\begin{array}{l}\text { Adhesion satisfactory, surface satis- } \\
\text { factory, } 2 \mathrm{H} \text { hardness }\end{array}$ \\
\hline$A-4 I$ & Shellac & Resin insoluble in solvent mixture \\
\hline$A-42$ & Staybelite 742 & $\begin{array}{l}\text { Adhesion satisfactory, surface good } \\
\text { less than } 2 \mathrm{H} \text { hardness }\end{array}$ \\
\hline$A-43$ & Amberol 750 & No adhesion, surface good, 7 H hardness \\
\hline$A-44$ & Amberol 226 & No adhesion, 3 H hardness, surface good \\
\hline
\end{tabular}


range of $F$ to $8 H$ was used for this work. Pencils of varying hardness are drawn with moderate pressure, across the film at an angle of $45^{\circ}$. The hardness of the pencil which cuts the surface of the film is given as the pencil hardness of the film.

The results obtained from first trial lacquers were used to make modifications for possible improvement of the film.

These modifications together with the results appear in Table III. The solvent was that employed previously. Nevillac $R F$ and Nevillac RT, in the modified lacquer, showed a continued lack of adhesion which ruled out the possibility of their use. Modifications of the other resins resulted in very soft coatings, with one exception. Adaitions of plasticizer to the lacquer containing Super Beckacite 3000 still produced a brittle film. As a further check on the resins, ethyl alcohol solutions were made of the resins, and these solutions were spread on tin panels. These flow-outs were then cured in an oven at $70^{\circ} \mathrm{C}$ for 2 hours; then they were examined for adhesion and hardness. The results for this work are given in Table IV. All the resins in a pure state exhibited brittleness. The major difference was found in the hardness. The resins were not considered for use unless the hardness of the pure material was above $5 \mathrm{H}$.

Those resins which showed a total lack of adhesion were eliminated immediately. The others were all dropped from 
Table III

Evaluation of Resins by Means of Modified Lacquers

\begin{tabular}{|c|c|c|c|c|c|c|}
\hline No. & Resin & 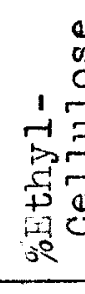 & $\begin{array}{l}\frac{1}{4} \\
0 \\
0 \\
0 \\
0 \\
0 \\
\end{array}$ & 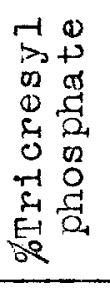 & Modification & Results \\
\hline$A-28$ & $\begin{array}{l}\text { Nevillac } \\
\operatorname{RP}\end{array}$ & 11 & 75 & 14 & $\begin{array}{l}\text { Decreased ethylcellu- } \\
\text { lose and increased } \\
\text { resin }\end{array}$ & $\begin{array}{l}\text { Adhesion } \\
\text { poor, brittle } \\
5 \mathrm{H} \text { hardness }\end{array}$ \\
\hline$A-29$ & Estergum & 15 & 75 & 10 & $\begin{array}{l}\text { Decreased ethylcellu- } \\
\text { lose \& plasticizer \& } \\
\text { increased resin }\end{array}$ & $\begin{array}{l}\text { Adhesion } \\
\text { fair, } 4 \mathrm{H} \\
\text { hardness }\end{array}$ \\
\hline$A-30$ & $\begin{array}{l}\text { Nevillac } \\
\text { Soft }\end{array}$ & 10 & 80 & 10 & $\begin{array}{l}\text { Decrease in plastici- } \\
\text { zer \& ethylcellulose. } \\
\text { Increase in resin }\end{array}$ & $\begin{array}{l}\text { Adhesion } \\
\text { poor, slight } \\
\text { brittleness, } \\
4 \text { H hardness }\end{array}$ \\
\hline$A-3 I$ & Pontianak & 36 & 50 & 14 & $\begin{array}{l}\text { Decrease in resin \& } \\
\text { increase in ethyl- } \\
\text { cellulose }\end{array}$ & $\begin{array}{l}\text { Adhesion } \\
\text { poor, decreased } \\
\text { hardness, } 3 \mathrm{H}\end{array}$ \\
\hline & Pontianak & & & & $\begin{array}{l}\text { Addition of plasti- } \\
\text { cizer }\end{array}$ & $\begin{array}{l}\text { No adhesion, } \\
\text { decreased } \\
\text { hardness, } \\
\text { brittle }\end{array}$ \\
\hline & $\begin{array}{l}\text { Nevillac } \\
\text { RT }\end{array}$ & & & & $\begin{array}{l}\text { Addition of plast1- } \\
\text { cizer }\end{array}$ & $\begin{array}{l}\text { No adhesion, } \\
\text { decreased } \\
\text { hardness } \\
\text { brittle }\end{array}$ \\
\hline & $\begin{array}{l}\text { KNevillac } \\
\text { RP }\end{array}$ & & & & $\begin{array}{l}\text { Addition of plasti- } \\
\text { cizer }\end{array}$ & $\begin{array}{l}\text { No adhesion, } \\
\text { decreased } \\
\text { hardness }\end{array}$ \\
\hline & $\begin{array}{l}\text { *Super Beck- } \\
\text { acite } 3000\end{array}$ & & & & $\begin{array}{l}\text { Addition of plasti- } \\
\text { cizer }\end{array}$ & $\begin{array}{l}\text { Brittie, fair } \\
\text { adhesion, } 6 \mathrm{H} \\
\text { hardness }\end{array}$ \\
\hline
\end{tabular}

*Additions of plasticizer to preliminary lacquer 


\section{Table IV}

Adhesion and Hardness

Tests on Films of Pure Resin

$\begin{array}{ll}\text { Resin } & \text { Results } \\ \text { Nevillac soft } & 4 \text { Hardness, slight brittleness } \\ \text { Durez } 550 & 3 \mathrm{H} \text { hardness } \\ \text { Nevillac RP } & 3 \mathrm{H} \text { hardness, some brittleness } \\ \text { Nevillac RT } & \text { Greater than } 4 \mathrm{H} \text { hardness, very brittle } \\ \text { Estergum \#74l } & 4-5 \mathrm{H} \text { hardness, brittle } \\ \text { Super Beckacite } 3000 & \text { Very brittle, hardness indeterminant } \\ \text { Nevillac Hard } & 7 \mathrm{H} \text { hardness, brittleness } \\ \text { Pontianak } 1472 & 6 \mathrm{H} \text { hardness, high brittleness } \\ \text { Shellac } & 5 \mathrm{H} \text { hardness, very brittle } \\ \text { Staybelite } 742 & 5 \mathrm{H} \text { hardness, slight brittleness } \\ \text { Amberol } 750 & 7 \mathrm{H} \text { hardness } \\ \text { Amberol } 226 & 4 \mathrm{H} \text { hardnes, slightly brittle }\end{array}$


consideration because of brittleness, softness, or a combination of the two. Further work with some of these resins may uncover methods of using them advantageously.

After selection of the resin to be used, Nevillac Hard, it was necessary to determine the proper solids composition; therefore a trilinear diagram was used. Regular triangular coordinate paper was employed, and the system Nevillac Hard Resin - Ethylcellulose - Tricresyl phosphate was investigated. Solids compositions were selected and lacquers made for testing purposes. These lacquers were sprayed and tested for gloss, hardness, and brittleness. After tabulation of the results, areas were marked on the diagram to indicate areas of satisfactory properties. The compositions selected for this work are found in Table $V$ and the resultant diagram appears as Fig. I. The adhesion of the sample lacquers is not given on the diagram since all points tested gave satisfactory results. Examination of the diagram showed the most acceptable solids composition to be

$\begin{array}{lr}\text { Nevillac Hard Resin } & 75 \% \\ \text { lo cp. Med. Ethylcellulose } & 20 \% \\ \text { Tricresyl phosphate } & 5 \%\end{array}$

This formulation gave $5 \mathrm{H}$ hardness, excellent adhesion, good gloss, and no brittleness. In the succeding work, this was the composition used.

After the first trial lacquers were prepared, the solvent formulation was changed at will, in order to obtain films which were suitable for test purposes. After defining 


\section{Experimental Compositions Used \\ In ploting the Trilinear Diagram}

\begin{tabular}{|c|c|c|c|c|}
\hline No. & $\begin{array}{l}\text { Ethyl- } \\
\text { Cellulose }\end{array}$ & $\begin{array}{l}\text { Nevillac } \\
\text { Hard }\end{array}$ & $\begin{array}{l}\text { Tricresyl } \\
\text { Phosphate }\end{array}$ & Results \\
\hline$A-17$ & 26 & 60 & 14 & $\begin{array}{l}\text { Adhesion excellent, gloss } \\
\text { good, 5-6H hardness }\end{array}$ \\
\hline$A-18$ & 10 & 70 & 20 & $\begin{array}{l}\text { Adhesion indeterminant, gloss } \\
\text { excellent, hardness indeterm- } \\
\text { inant }\end{array}$ \\
\hline$A-19$ & 15 & 70 & 15 & $\begin{array}{l}\text { Adhesion indeterminant, gloss } \\
\text { excellent, } 2 \mathrm{H} \text { hardness }\end{array}$ \\
\hline$A-20$ & 20 & 75 & 5 & $\begin{array}{l}\text { Adhesion excelient, gloss } \\
\text { excellent, } 5 \mathrm{H} \text { hardness }\end{array}$ \\
\hline $4-21$ & 25 & 65 & 10 & $\begin{array}{l}\text { Adhesion excellent, gloss } \\
\text { good, } 5 \text { H hardness }\end{array}$ \\
\hline$A-22$ & 35 & 55 & 10 & $\begin{array}{l}\text { Adhesion excellent, gloss } \\
\text { poor, } 6 \mathrm{H} \text { hardness }\end{array}$ \\
\hline$A-23$ & 35 & 45 & 20 & $\begin{array}{l}\text { Adhesion excellent, gloss } \\
\text { fair, } 5 \mathrm{H} \text { hardness }\end{array}$ \\
\hline$A-24$ & 40 & 45 & 15 & $\begin{array}{l}\text { Adhesion excellent, gloss } \\
\text { poor, } 5-6 \mathrm{H} \text { hardness }\end{array}$ \\
\hline$A-25$ & 40 & 55 & 5 & $\begin{array}{l}\text { Adhesion excellent, gloss } \\
\text { poor, } 5-6 \mathrm{H} \text { hardness }\end{array}$ \\
\hline$A-26$ & 55 & 30 & 15 & $\begin{array}{l}\text { Adhesion excellent, gloss } \\
\text { bad. } 6 \mathrm{H} \text { hardness }\end{array}$ \\
\hline$A-27$ & 65 & 25 & 10 & $\begin{array}{l}\text { Adhesion excellent, gloss } \\
\text { bad, } 3-4 \mathrm{H} \text { hardness }\end{array}$ \\
\hline$A-32$ & 19 & 80 & 1 & $\begin{array}{l}\text { Too brittle for adhesion } \\
\text { determination, } 5-6 \mathrm{H} \text { hardness }\end{array}$ \\
\hline$A-33$ & 20 & 77 & 3 & $\begin{array}{l}\text { Slightly brittle, adhesion } \\
\text { excellent, } 5 \mathrm{H} \text { hardness, good } \\
\text { gloss }\end{array}$ \\
\hline
\end{tabular}




$$
\text { Table V (Con't.) }
$$

Experimental Compositions Used

In Ploting the Trilinear Diagram

\begin{tabular}{|c|c|c|c|c|}
\hline No. & $\begin{array}{l}\text { Ethyl- } \\
\text { Cellulose }\end{array}$ & $\begin{array}{l}\text { Nevillac } \\
\text { Hard }\end{array}$ & $\begin{array}{l}\text { Tricresyl } \\
\text { Phosphate } \\
\end{array}$ & Results \\
\hline$A-34$ & 23 & 75 & 2 & $\begin{array}{l}\text { Brittle, adhesion excellent, } \\
7 \mathrm{H} \text { hardness, gloss good }\end{array}$ \\
\hline$A-35$ & 28 & 70 & 2 & $\begin{array}{l}\text { Slightly brittle, adhesion } \\
\text { excellent, } 6 \mathrm{H} \text { hardness, good } \\
\text { gloss }\end{array}$ \\
\hline
\end{tabular}




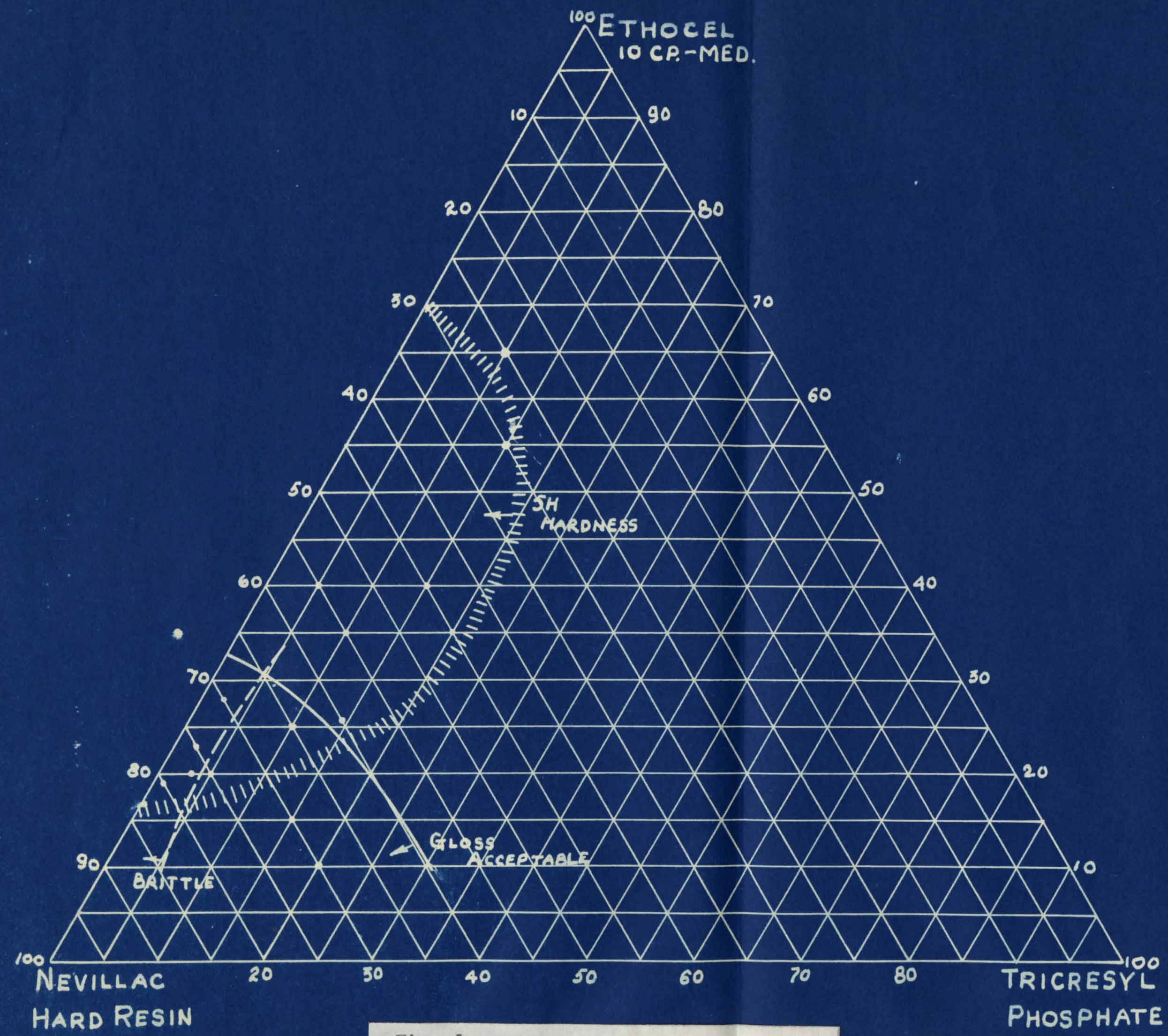


the solicis composition to be used, the proper solvent formulation was investigated. It had already been shown that the adhesion of the resin was satisfactory, and the solvent problem resolved itself into one of obtaining the desired spraying and drying characteristics. The majority of the solvent mixtures used this far had been very slow to aid the production of glossy films. During the tests made for the trilinear diagram, it was found that gloss improvement was to be obtained from proper solids formulation. This being the case, the drying rate of the lacquer could be increased without a decrease in gloss. The subsequent work was on this problem. In the last stages of drying, the appearance of a separate solvent phase was observed. On the assumption that one of the solvents in the mixture was evaporating at a rate very much slower than the other components, tests were conducted to determine the miscibility of the components in all proportiors. The solvents which had been used were n-Butanol, Ethanol, Isopropanol, Cellosolve, and Carbitol. These solvents were mixed in varying proportions, in which each material was allowed to predominate in the mixture. The mixtures were spread in a thin film on a porcelain plate, and a stream of air was blown over the surface. Observation of the samples was continued until completely evaporated. It was found that "puddles" similar to those previously noted were formed when Carbitol (ithylene glycol monoethyl ether) and cellosolve (Diethylene glycol monoethyl ether) were present in excess; 
therefore these two materials were eliminated from the solvent formulations. Ethanol, n-Butanol, and Isopropanol provided the range of evaporation rates necessary for producing a balanced solvent mixture, and hence, a solvent formulation was prepared from these materials. In order to eliminate the preparation of a large number of lacquers for testing solvent mixtures, the relative evaporation rates of several mixtures of solvents were determined. For this work, mixtures were prepared of the three components, ethanol, butanol, and isopropanol. Ten gram samples of these mixtures were then weighed into vessels of equal surface area (petrie dishes). The loss in weight, due to evaporation, was then recorded at intervals of 1 hour, 2 hours, 3 hours, and 5 hours. An integrated evaporation rate was then computed. After being graded in order of decreasing evaporation rate, the solvents were recorded as in Table VI and the results used for formulation. One trial lacquer was prepared and the drying characteristics observed. The solvent formulation was then changed, (faster, slower, etc.) as required by means of the relative evaporation rates. By this method, five lacquers were formulated as shown in Table VII. From these formulations, it was found that it was impossible to predict accurately the behavior of a lacquer by means of the relative evaporation rates of solvent mixtures. It appears that the evaporation of the solvont is influenced to a great extent by the presence of other lacquer constituents. Hence, 
Table VI

Relative Evaporation Rates of Solvent Mixtures

No. \%Ethyl \%Butyl \%Isopropyl Overall Evaporation Alcohol

\section{Alcohol}

1
2
3
4

160

$2 \quad 20$

$3 \quad--$

$4 \quad 80$

$5 \quad 50$

$6 \quad 100$

720

$8 \quad 60$

$9 \quad 80$

10 20

$11 \quad 10$

12

13

14

15

16

17

18

19

20
10
40

60

40

40

20

50

$--$

20

--

$\begin{array}{lr}-- & 40 \\ -- & 80 \\ -- & 100 \\ -- & 20 \\ - & 50\end{array}$

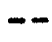

20

20

20

40

30

30

30

20

40

60

50

50

80

100
Alsopropy Alcohol

50

60

20

$\overline{40}$

60

30

10

40

20

20

$--$

50

-Rate GM/MIN

2.00

1.996

1.996

1.99

1.96

1.898

1.866

1.826

1.802

1.594

1.522

1.518

1.482

1.392

1.35

1.218

1.166

1.104

0.914

0.454 
Table VII

\begin{abstract}
Results on Lacquers Formulated by Means of Relative Evaporation Rates
\end{abstract}

\begin{tabular}{lcccl} 
No. & $\begin{array}{c}\text { \%Ethyl } \\
\text { Alcohol }\end{array}$ & $\begin{array}{c}\text { \% Butyl } \\
\text { Alcohol }\end{array}$ & $\begin{array}{c}\text { \% Isopropyl } \\
\text { Alcohol }\end{array}$ & Reults \\
\hline A-36 & 60 & 20 & 20 & Pinholes \\
A-37 & 60 & -- & 40 & $\begin{array}{l}\text { Pinholes } \\
\text { A-38 }\end{array}$ \\
& 40 & 20 & 40 & $\begin{array}{l}\text { O.K. slight } \\
\text { surface roughness }\end{array}$ \\
A-39 & 20 & 20 & 60 & Gassy, pinholes \\
A-40 & 20 & 60 & 20 & Slight pinholing
\end{tabular}


the work was continued by trial and error methods.

Lacquer A-38 showed very good characteristics in every respect with the exception of the final surface. Although the final surface was glossy, the surface itself contained minute irregularities. Trial and error methods showed that additions of Butanol corrected this condition considerably. Hence, trial lacquers were prepared, using the same solids formulation, but increasing the amount of Butanol. The results are recorded in Table VIII. It was noted that additions of Butanol above $40 \%$ did not have any effect on the condition of the surface. Formulation A-48 was then selected for further work. This lacquer was satisfactory from a coating point of view, but it was felt that it was not economical. At this point, the investigation was combined with the work on hydrocarbon solvents, Part 2, and reappears in part 3 .

Part 2: Hydrocarbon Solvents

It was known that polystyrene is soluble in all organic solvents with the exception of alcohols and petroleum derivatives. It was also known that many solvents, whether active solvents for polystyrene or not, crazed the plastic. For this reason, the preliminary work involved a survey of the solvent field to determine the effect of different types of solvent on the polystyrene surface. This examination was conducted with three points in mind. Solubility, crazing, and the condition of the surface of the 


\section{Table VIII}

Effect of Additions of $n$-Butanol to Formulation A-38

\begin{tabular}{|c|c|c|c|c|}
\hline No. & $\begin{array}{l}\text { \%Ethyl } \\
\text { Alcohol }\end{array}$ & $\begin{array}{l}\text { \% Butyl } \\
\text { Alcohol }\end{array}$ & $\begin{array}{c}\% \text { Is opropyl } \\
\text { Alcohol }\end{array}$ & Results \\
\hline$A-45$ & 37.5 & 25 & 37.5 & $\begin{array}{l}\text { Improved surface } \\
\text { Better than } A-38\end{array}$ \\
\hline$A-46$ & 35.0 & 30 & 35.0 & $\begin{array}{l}\text { Improved surface } \\
\text { Better than } A-45\end{array}$ \\
\hline$A-47$ & 32.5 & 35 & 32.5 & $\begin{array}{l}\text { Improved surface } \\
\text { Better than } A-46\end{array}$ \\
\hline$A-48$ & 30.0 & 40 & 30.0 & $\begin{array}{l}\text { Improved surface } \\
\text { Acceptable. Better } \\
\text { than } A-47\end{array}$ \\
\hline$A-49$ & 27.5 & 45 & 27.5 & No improvement \\
\hline
\end{tabular}


plastic were to be noted.

Crazing is a physical phenomenon which occurs in some plastic material as a result of interaction with solvent materials. The exact mechanism of this effect is unknown, but the results are well known. The effect is evidenced in several ways. The plastic surface is attacked in a manner which renders it opaque, because of the diffusion of light by the minute cracks in the surface of the plastic. A second effect is a decided roughening of the plastic surface. The third effect and probably the least desirable is the formation of deep cracks throughout the body of the plastic. This resembles the failure of "Safety Glass" in that the visible evidence is a network of cracks which gives a scintillating or opalescent appearance to the plastic shape. The physical appearance is not necessarily undesirable, but the condition indicates a weakening of the plastic. Under extreme conditions in fabricated forms, crazing may result in the spontaneous destruction of the item. The condition of the surface which was to be investigated was that due to solubility. Thus, when polystyrene is dissolved and the solvent allowed to evaporate, the redeposited polystyrene does not possess the smooth finish of the original plastic. The solubility to be noted is in no need of explanation.

The solvent tests were carried out on small pieces of plastic which were cut from larger molded disks. These 
small pieces were then spot tested. A small amount of solvent was evenly spread on the surface. Examination was then made for solvency and crazing. After observation of the immediate effects, the panels were allowed to stand until dry and were then re-examined. In no case was there any difference between the immediate and prolonged effects. Thus, if the solvent crazed the plastic at all, it did so immediately after application. When tests of mixtures were to be made, a drop of one solvent was placed on the panel. Smali amounts of a second solvent were then added to the original drop until the solvent mixture was predominantly composed of the second solvent. At each addition, the solvents were thoroughly mixed. By means of this method, the effects of various solvent proportions could be observed. In recording the results, the general or overall effect was reported. During the tests, the comparative results were based upon rapidity of action, viscosity of resulting solution, and depth of solvent action. For the crazing effect, rapidity of action was again taken into consideration, as was the degree of opacity imparted. In Table IX the results are presented. In every case, the crazing effect is noted, while the solvency and surface effects are recorded only when they are different from those of the pure solvents.

A study was also made of the effect of plasticizers upon polystyrene plastic. The method originally used was the application of small amounts of plasticizer to the plastic 
Table IX

Effect of Solvent Cornbinations for Plastic

\begin{tabular}{|c|c|c|c|c|c|c|}
\hline Solvents & Acetone & Solvesso \#I & $\begin{array}{c}\text { Carbon } \\
\text { Tetrachloride }\end{array}$ & Tolusol & Ethanol & Butanol \\
\hline Acetone & $\begin{array}{l}\text { si. sol. } \\
\text { high cr. }\end{array}$ & $\begin{array}{l}\text { no cr. } \\
\text { high sol. } \\
\text { heavy S.E. }\end{array}$ & $\begin{array}{l}\text { no cr. } \\
\text { high sol. } \\
\text { sl. s.t. }\end{array}$ & high cr. & no effect & sl. cr. \\
\hline Solvesso \#1 & $\begin{array}{l}\text { high sol. } \\
\text { nocr. } \\
\text { heavy S.T. }\end{array}$ & $\begin{array}{l}\text { sl. sol. } \\
\text { sl. cr. }\end{array}$ & no & no $\mathrm{cr}$. & bad cr. & bad cr. \\
\hline $\begin{array}{l}\text { Carbon } \\
\text { Tetrachloride }\end{array}$ & $\begin{array}{l}\text { no cr. } \\
\text { high sol. } \\
\text { light s. }\end{array}$ & no $\mathrm{cr}$. & sI. sol. & no $\mathrm{cr}$. & sl. cr. & def. cr. \\
\hline Tolusol & high cr. & no cr. & no cr. & & no $\mathrm{cr}$. & no $\mathrm{cr}$. \\
\hline Ethanol & no effect & bad cr. & sl. cr. & no cr. & no effect & no effect \\
\hline Butanol & sl. cr. & bad cr. & def. cr. & no cr. & no effect & no effect \\
\hline Mineral Spirits & high cr. & sl. cr. & sl. cr. & immisc. & no effect & sl. cr. \\
\hline Shell TS-28 & high cr. & no effect & no $\mathrm{cr}$. & no cr. & $\begin{array}{l}\text { no cr. } \\
\text { high sol. }\end{array}$ & some cr. \\
\hline Xylene & $\begin{array}{l}\text { no cr. } \\
\text { high sol. }\end{array}$ & $\begin{array}{l}\text { no } \mathrm{cr} . \\
\text { sl. sol. }\end{array}$ & no $\mathrm{cr}$. & no $\mathrm{cr}$ & sl. cr. & some cr. \\
\hline Vlise Naptha & high cr. & no $\mathrm{cr}$. & some cr. & sl. cr. & no cr. & some cr. \\
\hline Toluene & $\begin{array}{l}\text { no cr. } \\
\text { high } \mathrm{S} . \mathrm{k} \text {. }\end{array}$ & no cr. & no $\mathrm{cr}$. & no cr. & sl. cr. & crazing \\
\hline Troluoil & high cr. & no $\mathrm{cr}$. & no cr. & no cr. & no $\mathrm{cr}$. & crazing \\
\hline Ethyl Acetate & much cr. & no cr. & no cr. & $\begin{array}{l}\text { no cr. } \\
\text { high } S . H_{.}\end{array}$ & sl. cr. & crazing \\
\hline Alkazene \#13 & $\begin{array}{l}\text { no } \mathrm{cr} . \\
\text { no } \mathrm{S} . \mathrm{E}_{\mathrm{i}} \\
\text { sl. sol. }\end{array}$ & no cr. & no cr. & no cr. & no $\mathrm{cr}$. & no $\in$ ffect \\
\hline $\begin{array}{l}\text { Isopropy } 1 \\
\text { Benzene }\end{array}$ & $\begin{array}{l}\text { no cr. } \\
\text { sl. S.t. } \\
\text { sl. sol. }\end{array}$ & no cr. & no cr. & no $\mathrm{cr}^{2}$ & no cr. & no effect \\
\hline Tetralin & $\begin{array}{l}\text { no cr. } \\
\text { heavy } S . j . \\
\text { high sol. }\end{array}$ & no cr. & no cr. & sl. cr. & sl. cr. & crazing \\
\hline
\end{tabular}


Table IX (Con't.)

Effect of Solvent Combinations for Plastic

\begin{tabular}{|c|c|c|c|c|c|c|}
\hline Solvents & $\begin{array}{l}\text { Wineral } \\
\text { Spirits }\end{array}$ & $\begin{array}{l}\text { She } 11 \\
\text { TS-28 }\end{array}$ & Xylene & $\begin{array}{l}\text { V.M.\&P. } \\
\text { Naptha }\end{array}$ & Toluene & Troluoil \\
\hline Acetone & high cr. & high cr. & $\begin{array}{l}\text { no cr. } \\
\text { high sol. }\end{array}$ & high cr. & $\begin{array}{l}\text { no cr. } \\
\text { heavy } \mathrm{s} . \mathrm{H} \text {. }\end{array}$ & high cr. \\
\hline Solvesso \#1 & sl. cr. & no effect & $\begin{array}{l}\text { no cr. } \\
\text { sl. sol. }\end{array}$ & no cr. & no $\mathrm{cr}$. & $\begin{array}{c}\text { no } \\
\text { cr. }\end{array}$ \\
\hline Carbon & & & & & & \\
\hline Tetrachloride & sl. cr. & no $\mathrm{cr}$. & no cr. & some $\mathrm{cr}$. & no $\mathrm{cr}$. & no $\mathrm{cr}$. \\
\hline Tolusol & immisc. & no cr. & no $\mathrm{cr}$. & sl. cr. & no cr. & no cr. \\
\hline Ethanol & no effect & $\begin{array}{l}\text { no cr. } \\
\text { high sol. }\end{array}$ & sl. cr. & no cr. & sl. cr. & no cr. \\
\hline Butanol & sl. cr. & crazing & crazing & crazing & crazing & crazing \\
\hline Mineral Spirits & no effect & crazing & no cr. & no cr. & no $\mathrm{cr}$. & si. cr. \\
\hline$S h \in 11$ TS -28 & crazing & s1. sol. & no $\mathrm{cr}$. & bad cr. & no cr. & crazing \\
\hline Xylene & no cr. & no cr. & good sol. & no cr. & no cr. & no cr. \\
\hline VN\&P Naptha & no cr. & bad cr. & no cr. & $\begin{array}{l}\text { no sol. } \\
\text { bad cr. }\end{array}$ & no cr. & crazing \\
\hline Toluene & no cr. & no $\mathrm{cr}$. & no cr. & no $\mathrm{cr}$ & high sol. & crazing \\
\hline Troluoil & sl. cr. & some cr. & no cr. & some cr. & crazing & $\begin{array}{l}\text { sl. sol. } \\
\text { high cr. }\end{array}$ \\
\hline Etryl Acetate & crazing & some $\mathrm{cr}^{2}$ & no $\mathrm{cr}$ & sl. $\mathrm{cr}$ & no $\mathrm{cr}$. & v.sl.cr. \\
\hline Alkazene $\# 13$ & no effect & no effect & no effect & no effect & $\mathrm{v} . \mathrm{s} 1 . \mathrm{cr}$. & no $\mathrm{cr}$. \\
\hline Isopropyl & no effect & no effect & no effect & no cr. & no effect & no cr. \\
\hline Tetralin & no cr. & no cr. & no cr. & no $\mathrm{cr}$ & no cr. & no $\mathrm{cr}$. \\
\hline Decalin & no cr. & no effect & no effect & sl. cr. & no $\mathrm{cr}$. & some cr. \\
\hline
\end{tabular}


Table IX (Con't.)

Effect of Solvent Combinations for Plastic

\begin{tabular}{|c|c|c|c|c|c|}
\hline Solvents & Ethyl Acetate & Alkazene & $\begin{array}{l}\text { Isopropy } 1 \\
\text { Benzene }\end{array}$ & Tetralin & Decalin \\
\hline Acetone & high cr. & $\begin{array}{l}\text { no } \mathrm{cr} . \\
\text { no } \mathrm{s} . \mathrm{H}_{\text {. }} \\
\text { sl. sol. }\end{array}$ & no cr. & no cr. & high cr. \\
\hline $\begin{array}{l}\text { Solvesso \#l } \\
\text { Carbon }\end{array}$ & no $\mathrm{cr}$. & no $\mathrm{cr}$. & no cr. & no $\mathrm{cr}$. & no cr. \\
\hline Tetrachloride & no cr. & no $\mathrm{cr}$. & no $\mathrm{cr}$. & no cr. & no cr. \\
\hline Tolusol & $\begin{array}{l}\text { no cr. } \\
\text { high } \mathrm{S} . \mathrm{H} \text {. }\end{array}$ & no $\mathrm{cr}$. & no cr. & no $\mathrm{cr}$. & no cr. \\
\hline $\begin{array}{l}\text { Ethanol } \\
\text { Butanol }\end{array}$ & $\begin{array}{l}\text { sl. cr. } \\
\text { crazing }\end{array}$ & $\begin{array}{l}\text { no cr. } \\
\text { no effect }\end{array}$ & $\begin{array}{l}\text { no cr. } \\
\text { no effect }\end{array}$ & $\begin{array}{l}\text { sl. cr. } \\
\text { crazing }\end{array}$ & $\begin{array}{l}\text { no cr. } \\
\text { crazing }\end{array}$ \\
\hline Mineral Spirits & crazing & no effect & no effect & no cr. & no cr. \\
\hline She 11 TS-28 & some cr. & no effect & no $\in f f \in c t$ & no cr. & no effect \\
\hline Xylene & no $\mathrm{cr}$. & no effect & no effect & no cr. & no effect \\
\hline WiP Naptha & sl. cr. & no effect & no effect & no cr. & sl. cr. \\
\hline Toluene & no cr. & v.sI.cr. & no effect & no $\mathrm{cr}$. & no $\mathrm{cr}$. \\
\hline Troluoil & $\mathrm{v} \cdot \mathrm{sI} \cdot \mathrm{cr}$. & no $\mathrm{cr}$. & no $\mathrm{cr}$. & no cr. & some cr. \\
\hline Ethyl Acetate & & no cr. & no cr. & no $\mathrm{cr}$. & no cr. \\
\hline $\begin{array}{l}\text { Alkazene \#13 } \\
\text { Isopropy } 1\end{array}$ & no cr. & no effect & no effect & no effect & no effect \\
\hline Benzene & no cr. & no effect & high sol. & no effect & no effect \\
\hline Tetralin & no $\mathrm{cr}$. & no effect & no effect & s1. sol. & no effect \\
\hline Decalin & no $\mathrm{cr}$. & no effect & no effect & no effect & V.SI.sol. \\
\hline
\end{tabular}

Note: sl., slight; immisc., immiscible; def., definite; cr., crazing; sol., solvency; S. H. surface effect. Ratings in order of increasing effect: 1), definite; 2), very slight; 3) slight; 4) some; 5 ) much; 6) high; 7) bad. 
surface and then observation of the results. It was found that the nature of the plasticizing materials obscured any effects present. To eliminate this difficulty, solutions of the various plasticizers were made, using $n$-Butanol. These solutions were then used for spot tests as before. After the tests, during which the immediate results were observed, the residual material was wiped from the panel, and the surface beneath was examined. For a representative group of plasticizers the results showed that the materials have no effect upon the panel. Pertinent data about these tests appear in Table $X$.

Formulation was then begun. The method applied to this work was largely trial and error. A formulation was prepared, and then changes were made as necessary. In several cases it was found necessary to back-track since some of the results were misinterpreted. During the course of investigation various ideas presented themselves, and these were investigated until their value was proved or disproved. All the formulations prepared for this part of the work appear in Table XI. Those formulations which appear. in the table, but which are not discussed in the body of the thesis, were required to complete the data, but did not add enough to the investigation to warrant discussion. As a starting point, a lacquer formulation was selected for application in order to observe the exact behavior of the panel when coated. The formulation contained 
Table X

Plasticizer Spot Tests

Plasticizer

Application and Results

Dow $P-6$

Solution ineffective; no effect

Butyl sterate

Solution not necessary; no effect

Tricresyl phosphate

Solution not necessary; no effect

Chlorinated Diphenyl

Cut in butanol; no effect

Castor oil

Used alcohol solution; no effect

Aroplas 930

Used butanol solution; no effect 
Table XI

Formulation of Experimental Lacquers

\begin{tabular}{|c|c|c|c|c|c|c|c|c|c|}
\hline Number & $s-1$ & $s-2$ & $S-3$ & $S-4$ & $S-5$ & $s-6$ & $s-7$ & $s-8$ & $s-9$ \\
\hline 10cp Std. Ethylcellulose & 26 & 26 & 26 & 30 & 30 & 30 & 26 & 30 & 30 \\
\hline \multicolumn{10}{|l|}{ Plasticizer } \\
\hline Tricresyl Phosphate & 14 & 14 & 14 & 14 & 10 & 10 & 14 & 6 & -- \\
\hline Super Beckacite 2100 & -- & -- & -- & -- & -- & -- & -- & -- & -- \\
\hline Durez 550 & -- & -- & -- & -- & 60 & 60 & 60 & -- & 70 \\
\hline Durez 570 & -- & 60 & 60 & 60 & -- & -- & -- & -- & -- \\
\hline Nevillac Hard & -- & -- & -- & -- & -- & -- & - & -- & -- \\
\hline Bakelite RP 254 & 60 & -- & -- & -- & -- & -- & -- & -- & -- \\
\hline Ethyl alcohol & -- & -- & 60 & 70 & -- & -- & -- & 60 & 60 \\
\hline n-Butyl alcohol & 12 & 12 & -- & -- & -- & -- & -- & -- & -- \\
\hline Mineral Spirits & 56 & 56 & 35 & -- & -- & -- & 35 & 35 & 35 \\
\hline VM\& $\vec{P}$ Naptha & -- & -- & -- & 30 & 50 & 50 & -- & -- & -- \\
\hline Toluene & -- & -- & 5 & -- & -- & -- & 65 & 5 & 5 \\
\hline Xylene & -- & -- & -- & -- & 50 & -- & -- & -- & -- \\
\hline I-Nitropropane & -- & -- & -- & -- & -- & -- & -- & -- & -- \\
\hline$S h e 11 \mathrm{TS}-28$ & 32 & 32 & -- & -- & -- & 50 & -- & -- & -- \\
\hline
\end{tabular}


Table XI (con't.)

Formulation of Experimental Lacquers

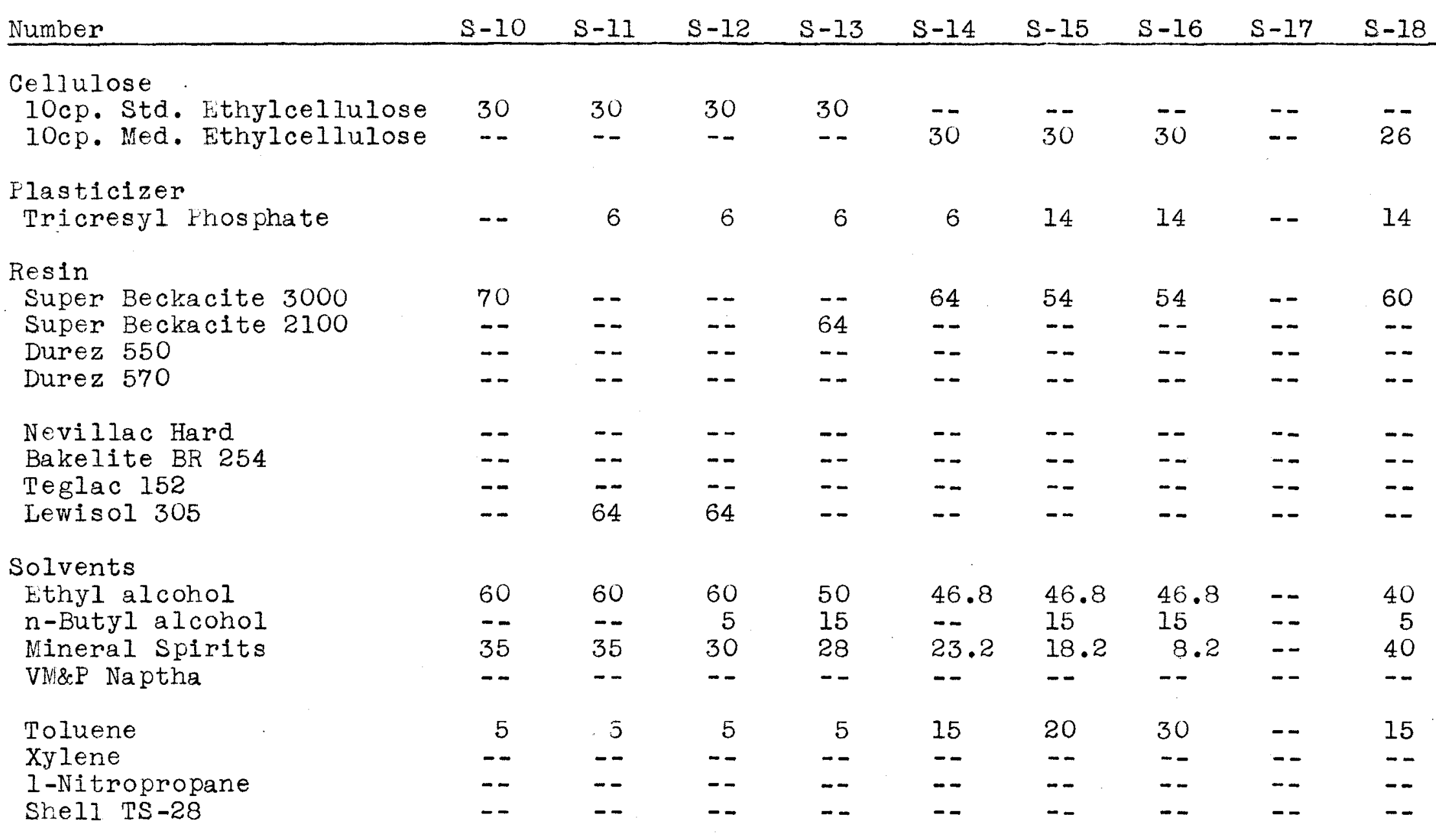


Table XI (Con't.)

Formulation of Experimental Lacquers

\begin{tabular}{|c|c|c|c|c|c|c|c|c|}
\hline Number & $S-19$ & $S-20$ & $s-21$ & $s-22$ & $S-23$ & $S-24$ & $s-25$ & $S-26$ \\
\hline \multicolumn{9}{|l|}{ Cellulose } \\
\hline locp. Std. Ethylcellulose & -- & -- & - & -- & -- & - & - & -- \\
\hline 10cp. Hed. Ethylcellulose & 26 & 26 & 26 & 20 & 20 & 16 & 24 & 26 \\
\hline \multicolumn{9}{|l|}{ Plasticizer } \\
\hline Tricresyl Phosphate & 14 & 14 & 14 & 20 & 24 & 24 & 20 & 14 \\
\hline \multicolumn{9}{|l|}{ Resin } \\
\hline Super Beckacite 3000 & 30 & 15 & 9 & 60 & 56 & 60 & 56 & 60 \\
\hline Super Beckacite 2100 & -- & -- & -- & -- & - & -- & -- & -- \\
\hline Durez 550 & 30 & 45 & 51 & -- & -- & -- & -- & -- \\
\hline Durez 570 & -- & -- & -- & -- & -- & -- & -- & -- \\
\hline Nevillac Hard & -- & -- & -- & -- & -- & -- & -- & -- \\
\hline Bakelite BR 254 & -- & -- & -- & -- & -- & -- & -- & -- \\
\hline Teglac 152 & -- & -- & -- & -- & -- & -- & -- & -- \\
\hline Lewisol 305 & -- & -- & -- & -- & -- & -- & -- & -- \\
\hline \multicolumn{9}{|l|}{ Solvents } \\
\hline Ethyl alcohol & 40 & 40 & 40 & 51.4 & 45 & 45 & 45 & 40 \\
\hline n-Butyl alcohol & 5 & 5 & 5 & 12.8 & 16 & 16 & 16 & 10 \\
\hline Mineral Spirits & 40 & 40 & 40 & -- & -- & -- & -- & 35 \\
\hline VM\&P Naptha & -- & -- & -- & -- & -- & -- & -- & -- \\
\hline Toluene & 15 & 15 & 15 & 19 & 19 & 19 & 19 & 15 \\
\hline Xylene & -- & -- & -- & -- & -- & -- & -- & -- \\
\hline 1-Nitropropane & -- & -- & -- & 16.8 & 20 & 20 & 20 & -- \\
\hline Shel1 TS-28 & -- & -- & -- & -- & -- & -- & -- & -- \\
\hline
\end{tabular}


Table XI (Con't.)

Formulation of Experimental Lacquers

\begin{tabular}{|c|c|c|c|c|c|c|c|c|c|}
\hline Number & $s-27$ & $S-28$ & $s-29$ & $S-30$ & $s-31$ & $s-32$ & $s-33$ & $s-34$ & $S-35$ \\
\hline $\begin{array}{l}\text { Butyl Stearate } \\
\text { Dibutyl Phthalate } \\
\text { Dow P-6 } \\
\text { Wethyl cellosolve stearate } \\
\text { Nevillac } 10^{\circ}\end{array}$ & $\begin{array}{l}-- \\
-- \\
-- \\
-- \\
--\end{array}$ & $\begin{array}{l}-- \\
-- \\
-- \\
--\end{array}$ & $\begin{array}{l}-- \\
-- \\
-- \\
-- \\
--\end{array}$ & $\begin{array}{l}-- \\
-- \\
-- \\
--\end{array}$ & $\begin{array}{l}14 \\
-- \\
-- \\
-- \\
--\end{array}$ & $\begin{array}{l}-- \\
14 \\
-- \\
-- \\
--\end{array}$ & $\begin{array}{l}-- \\
-\overline{14} \\
-- \\
--\end{array}$ & $\begin{array}{l}-- \\
-- \\
-- \\
14 \\
--\end{array}$ & $\begin{array}{l}-- \\
-- \\
-- \\
-- \\
14\end{array}$ \\
\hline $\begin{array}{l}\text { Solvents } \\
\text { Ethyl alcohol } \\
\text { n-Butyl alcohol } \\
\text { Mineral spirits } \\
\text { Toluene }\end{array}$ & $\begin{array}{l}40 \\
10 \\
35 \\
15\end{array}$ & $\begin{array}{l}40 \\
10 \\
35 \\
15\end{array}$ & $\begin{array}{l}40 \\
10 \\
35 \\
15\end{array}$ & $\begin{array}{l}40 \\
10 \\
35 \\
15\end{array}$ & $\begin{array}{l}40 \\
10 \\
35 \\
15\end{array}$ & $\begin{array}{l}40 \\
10 \\
35 \\
15\end{array}$ & $\begin{array}{l}40 \\
10 \\
35 \\
15\end{array}$ & $\begin{array}{l}40 \\
10 \\
35 \\
15\end{array}$ & $\begin{array}{l}40 \\
10 \\
35 \\
15\end{array}$ \\
\hline $\begin{array}{l}\text { WMrP Naptha } \\
\text { Xylene } \\
\text { l-Nitropropane } \\
\text { Shell TS-28 }\end{array}$ & $\begin{array}{l}-- \\
-- \\
--\end{array}$ & $\begin{array}{l}-- \\
-- \\
--\end{array}$ & $\begin{array}{l}-- \\
-- \\
-- \\
--\end{array}$ & $\begin{array}{l}-- \\
-- \\
--\end{array}$ & $\begin{array}{l}-- \\
-- \\
--\end{array}$ & $\begin{array}{l}-- \\
-- \\
--\end{array}$ & $\begin{array}{l}-- \\
-- \\
-- \\
--\end{array}$ & $\begin{array}{l}-- \\
-- \\
-- \\
--\end{array}$ & $\begin{array}{l}-- \\
-- \\
-- \\
--\end{array}$ \\
\hline
\end{tabular}


Table XI (Con't.)

Formulation of Experimental Lacquers

\begin{tabular}{|c|c|c|c|}
\hline Number & $\mathrm{S}-46$ & $S-47$ & $S-48$ \\
\hline $\begin{array}{l}\text { Cellulose } \\
\text { lOcp. Std. Ethylcellulose } \\
\text { locp. Ned. Ethylcellulose }\end{array}$ & $\overline{20}$ & $\overline{20}$ & $\overline{20}$ \\
\hline $\begin{array}{l}\text { Flasticizer } \\
\text { Tricresyl Fhosphate }\end{array}$ & 5 & 5 & 5 \\
\hline $\begin{array}{l}\text { Resin } \\
\text { Super Beckacite } 3000 \\
\text { Super Beckacite } 2100 \\
\text { Durez } 550 \\
\text { Durez } 570\end{array}$ & $\begin{array}{l}-- \\
-- \\
--\end{array}$ & $\begin{array}{l}-- \\
-- \\
--\end{array}$ & $\begin{array}{l}-- \\
-- \\
--\end{array}$ \\
\hline $\begin{array}{l}\text { Nevillac Hard } \\
\text { Bakelite BR } 254 \\
\text { Teglac } 152 \\
\text { Lewisol } 305\end{array}$ & $\begin{array}{l}75 \\
-- \\
-- \\
--\end{array}$ & $\begin{array}{l}75 \\
-- \\
--\end{array}$ & $\begin{array}{l}75 \\
-- \\
-- \\
--\end{array}$ \\
\hline $\begin{array}{l}\text { Solvents } \\
\text { Ethy1 alcohol } \\
\text { n-Butyl alcohol } \\
\text { Mineral Spirits } \\
\text { VM\&P Naptha }\end{array}$ & $\begin{array}{l}40 \\
10 \\
40 \\
--\end{array}$ & $\begin{array}{l}50 \\
20 \\
20 \\
--\end{array}$ & $\begin{array}{l}51.4 \\
12.8 \\
-- \\
--\end{array}$ \\
\hline $\begin{array}{l}\text { Toluene } \\
\text { Xylene } \\
\text { I-Nitropropane } \\
\text { Shell is-28 }\end{array}$ & $\begin{array}{l}10 \\
-- \\
-- \\
--\end{array}$ & $\begin{array}{l}10 \\
-- \\
-- \\
--\end{array}$ & $\begin{array}{l}19 \\
-- \\
16.8 \\
--\end{array}$ \\
\hline
\end{tabular}


Table XII

Formulation of Thinners for Experimental Lacquer

$\begin{array}{lccccc}\text { Number } & S-I & S-2 & S-3 & S-4 & S-5-S-48 \\ \text { Ethyl alcohol } & -- & -- & 40 & 50 & \\ \text { Butyl alcohol } & 35 & 35 & -- & -- & \text { Thinner of } \\ \text { Mineral spirits } & 15 & 15 & 40 & -- & \text { same composi- } \\ \text { Shell TS-28 } & 50 & 50 & -- & -- & \text { in preparing the } \\ \text { VMiP Naptha } & -- & -- & -- & 50 & \text { lacquer } \\ \text { Toluene } & -- & -- & 20 & - & \end{array}$


$50 \%$ solids composed of

$\begin{array}{ll}10 \text { cp. Std. Ethylcellulose } & 26 \% \\ \text { Resin } & 60 \% \\ \text { Plasticizer } & 14 \%\end{array}$

These solids were then used in a completed formulation which contained the following:

$\begin{array}{lll}\text { Solids } & 10 \mathrm{cp} \text {. Std. Ethylcellulose } & 26 \% \\ & \text { Resin } & 60 \% \\ \text { Plasticizer } & 14 \%\end{array}$

and solvent to make $50 \%$ solids

$\begin{array}{ll}\text { n-Butanol } & 12 \% \\ \text { Mineral spirits } & 56 \% \\ \text { Shell TS-28 } & 32 \%\end{array}$

In the first formulations, $S-1$, the resin used was Bakelite BR-254, and the plasticizer was Tricresyl phosphate. After a short mixing period, an incompatibility was noted. A second lacquer, $S-2$, was prepared using Durez 550 resin and Tricresyl phosphate plasticizer. The proportion and other ingredients were unchanged. When $S-2$ was completely mixed, it was so very viscous that an additional amount of solvent was added. This addition consisted of $50 \mathrm{gm}$. of solvent, containing the same material and proportions that were used In making up the original lacquer. Thus the final lacquer contained $331 / 3 \%$ solids. For application purposes the lacquer was cut $1: 1$ with

$$
\begin{array}{ll}
\text { n-Butanol } & 35 \% \\
\text { Shell TS-28 } & 50 \% \\
\text { Mineral spirits } & 15 \%
\end{array}
$$

The finished panel was unsatisfactory because of bad crazing, but showed the lines along which the investigation was to 
continue. A new lacquer, $\mathrm{s}-3$, was formulated using ethanol, mineral spirits, and toluene. The toluene was to serve the double purposes of giving bite and of making the ethanol and mineral spirits mutually soluble. The new solvent line-up was then

$\begin{array}{lr}\text { Ethanol } & 60 \% \\ \text { Mineral spirits } & 35 \% \\ \text { Toluene } & 5 \%\end{array}$

When this solvent was incorporated in the complete formulation, the results were

$\begin{array}{lll}\text { Solids } & 10 \mathrm{cp} . \text { Std. Ethylcellulose } & 26 \% \\ & \text { Resin } & 60 \% \\ & \text { Plasticizer } & \frac{14 \%}{100 \%}\end{array}$

prepared with $50 \%$ solids

$\begin{array}{llr}\text { Solvent } & \text { Ethanol } & 60 \% \\ \text { Mineral spirits } & 35 \% \\ \text { Toluene } & \frac{5 \%}{100 \%}\end{array}$

For the resin and plasticizer, Durez 550 and Tricresyl phosphate were used again, respectively. The resulting lacquer, in itself, had the proper appearance. This was then cut $2: 1$ with solvent prepared by mixing

$\begin{array}{ll}\text { Ethanol } & 40 \% \\ \text { Mineral spirits } & 40 \% \\ \text { Toluene } & 20 \%\end{array}$

When the thinned lacquer was sprayed, the panel crazed immediately. In order to determine the effect of the thinner some of $\mathrm{S}-3$ was cut with pure ethanol. The crazing showed definite improvement, but air bubbles were trapped in the lacquer surface because of the rapidity of evaporation. The 
surface appearance of this lacquer was good.

A review of the work, and further examination of the panels prepared this far, showed several points for consideration. The crazing which had been caused by the effect of mixing ethanol and toluene, could easily be eliminated by reworking the solvent line-up. At the same time, examination showed that the films were very soft. Because of this softness, it was difficult to obtain any index of the adhesion. At best, adhesion was only fair. At this time these facts would seem to call for a lower plasticizer content and a higher proportion of polystyrene solvent.

To include these points, a new formulation, $\mathrm{S}-4$, was proposed. The solids were

$\begin{array}{ll}10 \mathrm{cp} \text {. Std. Ethylcellulose } & 30 \% \\ \text { Resin } & 60 \% \\ \text { Plasticizer } & 10 \%\end{array}$

and the solvent consisted of

Ethanol

VW\&:P Naptha

$70 \%$

$30 \%$

producing a lacquer of $50 \%$ solids. In order to be able to relate this lacquer with those prepared previously, Durez 550 and Tricresyl phosphate were again employed. For spraying purposes, the lacquer was to be thinned $2: 1$ with

$\begin{array}{ll}\text { Ethanol } & 50 \% \\ \text { VM\&P Naptha } & 50 \%\end{array}$

When this thinner mixture was made, an immiscibility was found, which made it unsuitable for the work. This gave a hint of a difficulty which might be found in the lacquer 
itself. In order to check this condition some of the lacquer, in its thick state, was spread on a piece of plastic. When i it had dried, the surface was found to be good, but the film contained many bubbles. In addition, the film had no effect on the panel, was soft, and had no adhesion. Two of the difficulties noted in the formulation were eliminated by thining tre lacquer with VM\&P Naptha alone, producing a lacquer with slower drying characteristics, and resulting in the prevention of the formation of bubbles in the film. With this formulation, suitable coatings could be prepared if the adhesion were improved. Because of its inertness with regard to the panel, it seemed to be suited for investigation of surface treatment of the panel before coating. The idea behind this investigation was that the panel could be treated by a thin coating of some naterial which would attack the surface. This attack would roughen the surface slightly, whereupon a coating, inert with respect to the panel, might be applied. The slight roughness imparted by the first treatment would give the necessary adhesion to the final film. To carry out this surface treatment, small amounts of various solvents were sprayed on the panels by means of an atomizer. These treated panels were then coated and examined for adhesion. All the more common solvents were tried for this purpose, but none was satisfactory. The desired result could be achieved only with difficulty. This line of attack was abandoned because of the close control required 
in the treatment made it commercially unfeasible.

Returning to systems of active polystyrene solvent

in the lacquer, solvent mixtures with a minimum surface

effect were investigated, by using aromatics in conjunction with naphthas, aromatic naphthas and some of the less well known solvents. The surface effects of the mixtures were tested by preparing the solvent mixture and spraying it, by means of a medicinal atomizer, on a small portion of plastic panel. When a suitable mixture appeared, it was incorporated in a lacquer and tested by application. As a starting point, toluene mixtures were selected for investigation. Toluene was used with various other materials, as pointed out above, but in every case the surface effect was very bad. The second investigation involved xylene with similar results. The surface effect was decreased somewhat, and the overall effect made the system seem suitable for formulation.

A lacquer was then prepared using this solvent. S-5 was made with xylene and VMrP Naptha. In order to keep the results on a comparative basis, Durez 550 and Tricresyl phosphate were again used in the solids. This gave a lacquer of the following composition

Solids $50 \% \quad 10 \mathrm{cp}$. Std. Ethylcellulose Durez 550 Tricresyl phosphate

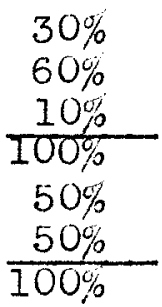

in

Solvent

Xylene

VM\&P Naptha 
This mixture was thinned as required with solvent of the same composition as the make-up. The coating resulting from this formulation was unsatisfactory. Other systems were tried, including Solvesso \#l, Lacquer diluent, diethyl benzene, ethyl acetate and acetone. These materials were used in mixtures with various naphthas. By comparison with the action of xylene and VH\&P Naptha, it was seen that none of these systems would be'satisfactory. This work was then discontinued.

of the formulations which had been prepared so far, only one, $\mathrm{S}-3$, had shown any real promise. This formulation gave a smooth film with minimum attack on the plastic base. This formulation was used for further study. The lacquer was thinned with mixtures of the make-up solvents in varying proportions. It was found that the thining solvent could be changed within wide limits, as long as the amount of toluene did not become too high (less than 10\% of the thining solvent). Thus the drying and spraying characteristics of the lacquer could be varied to satisfy almost any condition. The finished coats produced by $\mathrm{S}-3$ were smooth, but very soft and somewhat tacky. In order to eliminate these two difficulties, a change was indicated in both resin and plasticizer. For the change in plasticizer, $S-3$ was made in the original manner, but the plasticizer was omitted entirely in the solids formulation. For the change in resin, a hard phenolic, super Beckacite 3000, was substituted for Durez 550 which is soft and tacky. These formulations were numbered $S-S$ and $S-10$ and appear in Table XI. 
These formulations were thinned to spraying viscosity with a solvent mixture of the same composition as the make-up solvent. S-9 gave a coating which was harder than that of $\mathrm{S}-3$, but the surface was still tacky. $\mathrm{S}-10$ showed a considerable improvement over S-3, and was both hard and tack-free. S-10 was then used as the starting point for another series of investigations. The finished coating, though having several desirable properties, needed some modifications for better spraying characteristics. It was also desired to substitute medium ethoxy ethylcellulose for the standard. The first modification was number $\mathrm{S}-14$. In addition to the above modification, tricresyl phosphate was added to compensate for the loss in flexibility caused by the change in ethylcellulose. The S-14 formulation was
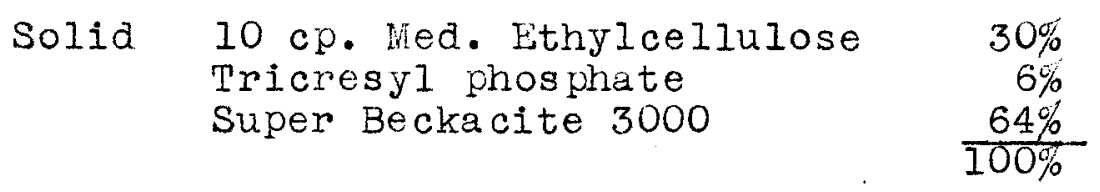

These solids were dissolved in the following solvent mixture until the desired viscosity was obtained.

$$
\begin{aligned}
& \text { Ethyl alcohol } \\
& \text { Mineral spirits } \\
& \text { Toluene } \\
& \text { n-Butyl alcohol }
\end{aligned}
$$$$
\begin{array}{r}
46.8 \% \\
23.2 \% \\
15 \% \\
15 \% \\
\hline 100 \%
\end{array}
$$

The finished lacquer sprayed easily and gave a smooth, hard coating, but the flexibility and adhesion were unsatisfactory. The solids content of this lacquer was modified as was the solvent contained. This work was done in formulation s-15-s-17. 
There resulted formulation $\mathrm{S}-18$

$$
\begin{array}{cc}
\text { Med. } 10 \text { Cp. Ethylcellulose } & 26 \% \\
\text { Durez } 550 & 60 \% \\
\text { Tricresyl phosphate } & 14 \%
\end{array}
$$

and $50 \%$ solids in

$\begin{array}{lr}\text { Ethyl alcohol } & 40 \% \\ \text { Mineral spirits } & 37 \% \\ \text { Toluene } & 15 \% \\ \text { Butyl alcohol } & 8 \%\end{array}$

After drying for 1 hour at $70^{\circ} \mathrm{C}$, this lacquer had a hard, adhesive coating. The hardness was almost 5H. SIight crazing appeared during the drying period. Formulations $\mathrm{s}-1 \mathrm{~S}$ S-25 were prepared in an effort to eliminate this defect, but the results were unsuccessful. The mineral spirits content of $\mathrm{s}-18$ was decreased. At the same time, adhesion was lost. Thus, it was seen that the adhesion in this formulation was derived from the action of the mineral spirits on the surface of the plastic. An attempt was made to substitute some material with less rigorous action for the mineral spirits. The best results were obtained using 1-nitropropane. Some improvement was noticed, but the results were still unsatisfactory.

In order to determine the effect of plasticizer on this formulation, lacquers S-26 - S-36 were prepared, and it was found that Tricresyl phosphate gave the most satisfactory results. At this point the experimental work was combined with the alcohol solvent work, Part 1 , and reappears in Part 3 . 


\section{Part 3: Combined Solvents \\ Up to this point, only one formulation, $S-48$, was} considered as a solution to the problem. This formulation was satisfactory from a coating point of view, but it was felt that the composition was not economical; therefore, an investigation was carried out to find a solvent with which butanol might be replaced wholly or in part. Because of the presence of the butanol in the lacquer, no substitute was found for part of the butanol. The materials which would not craze the plastic, in combination with butanol, were more expensive than the butanol itself. Replacement of all the butanol by some other solvent was tried, but all the materials which would serve as a replacement crazed the plastic surface. Thus, the formulation A-48 was selcted as the solution to the problem. The complete formulation is as follows

$$
\begin{array}{cc}
10 \mathrm{Cp} \text { Med. Ethylcellulose } & 20 \% \\
\text { Tricresyl phosphate } & 5 \% \\
\text { Nevillac Hard Resin } & 75 \%
\end{array}
$$

made into $50 \%$ solids solution with

$$
\begin{array}{ll}
\text { n-Butanol } & 40 \% \\
\text { Ethyl alcohol } & 30 \% \\
\text { Isopropyl alcohol (99\%) } & 30 \%
\end{array}
$$

The lacquer was pigmented with $\mathrm{TiO}_{2}$, which was incorporated by means of the roller mill. Fifty parts of pigment were used for 100 parts of total lacquer solids. This gave the finished composition 
Pigment

$10 \mathrm{Cp}$. Med. Ethylcellulose

Tricresyl phosphate

Nevillac Hard Resin

n-Butyl alcohol

Ethyl alcohol

Isopropyl alcohol (99\%)

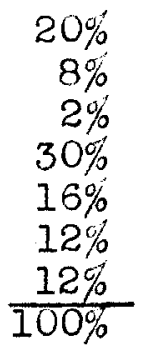

For spraying, this lacquer was thinned with 2 parts of solvent to 1 part of lacquer, using the same solvent composition as before. This lacquer was found to have $5 \mathrm{H}$ hardness, excellent adhesion, good gloss, freedom from sag, good leveling properties, and a drying time in an acceptable range. 
DISCUSSION 


\section{DISCUSSION}

Up to this point, the results of the work have been discussed in the experimental part of the thesis with respect to their influence upon the work. Several sideline investigations were presented as they were encountered, but the results and value of these investigations are in need of further discussion. Advantage will be taken of the opportunity to present this material here.

One of the systems considered was the activation of the plastic surface prior to the application of an inert lacquer coating. The activation of the surface was a treatment of the plastic with some polystyrene solvent which would open minute fissures in the surface. Upon aplication, the lacquer, inert with respect to the plastic, would flow into the cracks and thus adhere to the surface. The principle involved here is not new. In industrial practice, metals are given a surface treatment (Bonderizing, Parkerizing, etc.) before coating, to increase adhesion. A similar technique was investigated for polystyrene. The logical starting point was an examination of polystyrene solvents. These materials were unsatisfactory because they did not cause the formation of the necessary cracks in the plastic. Solvents which crazed the plastic were next tried, and although they produced the required cracks the action was too rigorous and the coated surface was not smooth. In an effort to retain the action, but decrease the vigorousness, these solvents were diluted 
with other materials which had no effect on the plastic. The dilution served its purpose to a certain extent, but great care was required in the application of the solvent mixture to prevent excessive action. On a basis of the observations, this method offers a solution to the problem only as a last resort. The great amount of control necessary in the application of the activating material makes the precedure unattractive commercially. The fact that two operations would be required for each article makes the system more undesirable. Hence, investigations along this line were discontinued.

The solvent spot tests disclosed one of the unusual aspects of this problem. The pure solvents had varying effects on the plastic, but the effect of these solvents in combination with others might be totally different. This fact greatly limited the usable solvent combination. The only solvent mixtures which even approached a solution to the problem, and containing solvents other than alcohols, was formulation S-18. The solvent was a complex misture of hydrocarbons and alcohols. The coatings produced by the use of $S-18$ were completely satisfactory with the exception of a very slight amount of crazing. For some uses the formulation would be acceptable. Attempts to modify S-18 slightly were unsuccessful. Solvent mixtures containing only alcohols offered no problem in attack of the surface but adhesion difficulties were encountered. The proper selection of a resin imparted the required adhesion, and gave an answer to the problem. 
When formulating the lacquers containing only

alcohols, a method was introduced which decreased the amount of trial and error investigation. The relative evaporation rates of solvent mixtures were determined and were plotted on a trilinear diagram. Lines of equal evaporation rate were then constructed. The data were found to be too incomplete to make a chart of this kind practical, and therefore the raw data were used as explained in the experimental part. The use of the rate data eliminated a large part of the guesswork involved in formulating an original lacquer. In the final analysis some trial and error formulations were required since the characterics of evaporation of the solvent mixtures were changed somewhat by the addition of the other lacquer components. 
SUMMARY AND COICIJUSIONS 


\section{SUMAARY AND CONCLUSIONS}

The investigation was carried out in two parts: first, the formulation of lacquers containing only alcohols for solvent; second, the formulation of lacquers employing only hydrocarbon solvents.

For part one, a number of resins were examined to evaluate their hardness, gloss, and adhesive properties. From these tests one resin was selected for use in the remainder of the investigation. A trilinear diagram was prepared for the system Ethylcellulose - Tricresyl phosphate - Nevillac Hard Resin as an aid in choosing the proper solids composition in the final lacquer. By means of experimentally determined evaporation rates a primary solvent formulation was prepared. This was modified to, produce a solvent mixture with satisfactory properties. This solvent in combination produced the lacquer which was considered the solution to the problem in this part. This formulation was ultimately the answer to the problem.

The second part of work was carried ut in a trial and error ranner. Several ex erimental formulations were prepared with no concrete results. It was then felt that a surface activating treatment prior to the application of an inert coating might be a solution to the problem. A series of examinations along this line showed that the system would not be satisfactory. Experimental formulation was then continued on the basis of solvent spot tests concucted previously. 
Each formulation was prepared as a modification of the preceding lacquer as was indicated by the results. After the preparation of a large number of lacquers, this work was abandoned in favor of the lacquer formulated in the work with alcohol solvents.

An attempt to modify the final alcohol solvent lacquer, by means of hydrocarbon solvents, was made in the interests of economy. Several lacquers were prepared with this idea in mind, but the results were not satisfactory. The alcohol-solvent lacquer was then selected, unchanged, as the final answer to the problem.

The lacquer was pigmented with $\mathrm{TiO}_{2}$, to produce the following composition

\begin{tabular}{lr} 
Pigment & $20 \%$ \\
locp. ied. Ethylcellulose & $8 \%$ \\
Tricresyl phosphate & $2 \%$ \\
Nevilic Hard Resin & $30 \%$ \\
Ethyl alcohol & $16 \%$ \\
n-Butyl alcohol & $12 \%$ \\
Isopropyl alcohol (99\%) & $12 \%$ \\
\hline $100 \%$
\end{tabular}

Good gloss, hardness, adhesion, leveling, and freedom from sag were obtained, and the requirements of the problem were fulfilled. 


\section{LITERATURE CITED}

(1) Bass, L.T. and Kauppi, T.A., Ind. Lng. Chem. 29, 678, $(1937)$

(2) Bass, S.T., Kauppi, T.A. and Sheck, J.I., Paint, Oil and Chem. Review, Niay (1937)

(3) Bethelot, M., Ann., 142, 257 (1867)

(4) Bigelow, Monats, 26, 413-27 (1905)

(5) Company Publication, "Drying Oils and Ethocel", Dow Chemical Company, Midland, Michigan (1937)

(6) Denham, W. and Woodhouse, H.J., Chem. Sec 103, 1725 (1913) $105,2357(1914)$

(7) Dow Chemical Company, "Ethocel Handbook" (1940)

(8) Dreyfus, $\mathrm{H}$, Br. Hatent 462, 272 (1937)

(5) Eilis, C., "The Chemistry of Synthetic Resins" Vol. I, pp. 232-262, New York, New York, Reinhold Pub. Co. (1935)

(10) Graef, A.W., Thesis for Master of Chemical Engineering, University of Louisvilie, (1940)

(11) Hercules Powder Co., "Ethyl Cellulose" (1940)

(12) Hulette, V.H. Jr., Thesis for Master of Chemical Engineering, University of Louisville (1941)

(13) Hutchison, I.W. Jr., Thesis for Master of Chemical Engineering, University of Louisville (1940)

(14) Leuchs, 0., German Patent 322, 586 (1920)

(15) Lilienfeld, L., Br. Patents 12,854 (1912) and 6035 (1813)

(16) Watthews, F.E., Br. Patent 16277 (1911)

(17) Matthews, F.E., J.S.C.I. 32,886 (1912)

(18) Mattiello, J.J., "Protective and Decorative Coatings" Vol I, pp 759-803, New York, New York, John Wiley \& Sons, Inc. (1941) 
(19) Mattiello, J.J., "Protective and Decorative Coatings" Vol. III, pp 497-567, New York, New York, John Wiley $\&$ Sons, Inc. (1943)

(20) Maynard, Boston Med. \& Sci. S., 38, 266, (1848)

(21) Modern Plastics Catlog, New York, Plastics Catalog Corp. (1943)

(22) Parkes, A., Br. Patent 2,359 (1855)

(23) Peterson, J., Thesis for Master of Chemical Engineering, University of Louisville, (1938)

(24) Scott, J.B., Thesis for Naster of Chemical Ingineering, University of Louisvilie (1940)

(25) Sheck, J.I. and reterson, N.R., Company Publication, Dow Chemical Company, Midiand, Michigan (1938)

(26) Simon, E., Ann., 31, 267 (1839)

(27) Stevens, J. McE., Paint, 011 \& Chem. Review 96, $8,(1934)$

(28) Suida, W., Monats, 26, 413-27 (1905)

(29) Worden, E.C., "Technology of Cellulose Ethers", Vol. I, pp 2-306; Vol. III pp 110-1410, Newark, New Jersey, Neward Printing Co. (1933)

(30) Zabban, 溥., Thesis for Master of Chemical Fingineering, University of Louisvilie (1944) 
Acknowledgement

The author takes this opportunity to thank the Dow Chemical Company, Midland, Michigan, which sponsored this fellowship. Furthermore he wishes to thank Thomas Carroll and David Spitzer who kindly assisted him with his research during the past year. 
VITA

Stuart V. Heil was born in Louisville, Kentucky on June 9, 1924, the son of Joseph Heil and queen Votteler Heil. He received his primary school education in the public schools of Louisville and completed his high school work at the duPont Manual Training High School in the same city. He received a Bachelor of Chemical Engineering degree from the University of Louisville in June, 1\&45, and continued his studies at that school with a fellowship sponsored by the Dow Chemical Company, Midiand, Michigan. He received his Master of Chemical Engineering degree in December 1946 . Upon completion of his academic work he went into the employ of The Buckeye Cotton 011 Company in the position of Chemical Supervisor.

Mr. Heil is a member of the American Chemical Society and Theta Chi Delta, National honorary chemical fraternity. During his undergraduate work, he was a member of the Student Chapter of the A.I.Ch.E. at the University. 